\title{
Pinturas novohispanas en España: responsables, finalidad y procedimiento
}

\author{
Patricia Barea Azcón
}

Facultad de Filosofía y Letras. Universidad de Granada

Actualmente se conserva en España un significativo conjunto de pintura virreinal mexicana de los siglos XVII y XVIII distribuido entre museos, instituciones religiosas y colecciones particulares. En la mayoría de los casos se trata de óleos pintados sobre lienzo que tienen como tema iconográfico a la Virgen de Guadalupe. Aunque se localizan en todas las comunidades, encontramos mayor presencia en las que estuvieron más vinculadas con el virreinato, entre las que hay que destacar Andalucía Occidental. Uno de los aspectos más interesantes y desconocidos es el referido al procedimiento de llegada de estas obras, en el que intervinieron factores de diversa índole y en el que subyacen cuestiones como a) quiénes fueron los protagonistas, b) cuál fue su propósito, c) qué método emplearon, d) a dónde fueron a parar, y en última instancia, e) cuál es el trasfondo del mismo.

Palabras Clave: México, virreinato de Nueva España, España, pintura virreinal, Virgen de Guadalupe, devoción, transporte, indianos.

Nowadays a significant amount of mexican colonial painting belonging to XVII and XVIII centuries remains in Spain and they are distributed among museums, religious institutiones and private collections. In the most of the cases they are oils painted over canvas which iconographic theme is the Virgin of Guadalupe. Althought they are located in whatever region, most of them are found in the places close bounder to the viceroyalty, being of particular interest those located in the western part of Andalucia (Spain). One of the most interesting but unknown aspect is that concerning to the paintings arrival process in which several factors are involved and underlie questions like a) who were the main figures, $b$ ) which was their purpuse, $c$ ) What methodology they used, d) where paintings finally arrived, and e) which was the background of this process.

KEYWORDs: México, viceroyalty of New Spain, colonial painting, Virgin of Guadalupe, devotion, Spain, transport, spaniard who has made good in America.

Investigaciones recientes señalan la presencia en España de gran cantidad de pinturas originarias del virreinato de Nueva España. Existe abundante información acerca de la pintura española conservada actualmente en México y su influencia en la formación de la escuela de pintura mexicana, en cambio aún quedan muchos datos por conocer sobre la pintura novohis- 


\section{pana situada en nuestro país y los avatares que incidieron en su proceso de llegada.}

Muchas de estas obras fueron traídas a España por los emigrantes españoles afincados en el virreinato, y hoy día se cuentan por centenares - sobretodo las que tienen como tema a la Virgen de Guadalupe mexicana-, repartidas en instituciones religiosas y domicilios particulares, constituyendo el testimonio de un rico intercambio cultural en el que intervinieron distinta clase de factores.

Son varias las cuestiones que debemos hacernos para conocer este asunto en profundidad: ¿quién las trajo?, ¿a dónde fueron a parar?, ¿cuál era su finalidad?, ¿por qué medio llegaban? Una visión algo más amplia

1 Una de las primeras aportaciones importantes fue la que hizo el historiador mexicano Estrada, Genaro: El arte mexicano conservado en España, Porrua, México, 1937. Más recientemente algunos autores han publicado interesantes estudios sobre obras novohispanas localizadas en la geografía española y sus principales iconografías. Entre ellos podemos citar a García Sáiz, María Concepción: La pintura colonial en el Museo de América, 2 vol., Ministerio de Cultura, Madrid, 1980; "Arte colonial mexicano en España”, Artes de México, $n .^{\circ}$ 22, Jean Paul Getty Trust, México, 1993-1994, págs. 26-38 y Cuadriello, Jaime: "La propagación de las devociones novohispanas: las Guadalupanas y otras imágenes preferentes", Discursos en el Arte. XV Coloquio Internacional de Historia del Arte, Instituto de Investigaciones Estéticas, México, 1991, págs. 257-293. Refiriéndose a zonas concretas, cabe citar los trabajos de Casaseca Casaseca, Antonio: "Arte colonial en Salamanca", Relaciones artísticas entre la Península Ibérica y América, Actas del V Simposio Hispano-Portugués de $H^{a}$ del Arte, Valladolid, 1989, Universidad de Valladolid, Junta de Castilla y León, Valladolid, 1990, págs. 59-67; Clavijo García, Agustín: "Pintura colonial en Málaga y su provincia", VV.AA.: Andalucía y América en el siglo XVIII, Escuela de Estudios Hispano-Americanos, Sevilla, 1985, págs. 89-117; Esteras Martín, Cristina: "Presencia del arte novohispano en la Baja Extremadura", Hernán Cortés, hombre de empresa. Primer Congreso de Americanistas, Badajoz, 1985, Publicaciones de la Casa-Museo de Colón y Seminario Americanista de la Universidad, Valladolid, 1990, págs. 288-290; Martínez de la Peña, Domingo: "Pinturas mejicanas del siglo XVIII en Tenerife", Anuario de Estudios Atlánticos, Madrid-Las Palmas, $n^{\circ}{ }^{\circ}$ 23, Casa-Museo de Colón, Las Palmas de Gran Canaria, 1977, págs. 583-601; Fraga González, Carmen: "Nueva relación de pinturas mexicanas en Canarias", V Coloquio de Historia Canario-americana, tomo I, segunda parte, Mancomunidad Provincial Interinsular de Cabildos de Las Palmas, Las Palmas de Gran Canaria, 1982, págs. 889-908; González Moreno, Joaquín: Iconografía guadalupana en Andalucía, Junta de Andalucía, Jerez de la Frontera —Cádiz—, 1991; Heredia Moreno, María del Carmen, Orbe Sivatte, Mercedes y Orbe Sivatte, Antonia: Arte hispanoamericano en Navarra, Gobierno de Navarra, 1992; Ibáñez Pérez, Alberto: "Relaciones artísticas ente Burgos y América. La Virgen de Guadalupe en Burgos", Relaciones artísticas entre la Península Ibérica y América, Actas del V Simposio Hispano-Portugués de $H^{a}$ del Arte, Valladolid, 1989, Universidad de Valladolid, Junta de Castilla y León, Valladolid, 1990, págs. 139-148; Moreno, Salvador: "Guadalupismo mexicano en Cádiz”, Cádiz-Iberoamérica, n. ${ }^{\circ}$ 2, Universidad de Cádiz, Cádiz, 1984, págs. 28-29; López Jiménez, José Crisanto: "Pinturas mexicanas en Murcia y un tríptico murciano de Nuestra Señora de Guadalupe", Anales del Instituto de Investigaciones Estéticas, $n .^{\circ} 32$, Instituto de Investigaciones Estéticas, Universidad Nacional Autónoma de México, México, 1962, págs. 59-64); Sebastián López, Santiago: "Iconografía guadalupana en Palma de Mallorca", Anales del Instituto de Investigaciones Estéticas, $n$. 44, Instituto de Investigaciones Estéticas, Universidad Nacional Autónoma de México, México, 1975, págs. 65-67) o Zorrozúa Santisteban, Julen: "Representaciones de la Virgen de Guadalupe en Vizcaya", Letras de Deustro, . $^{\circ} 73$, vol. 26, Oct-Dic. 1996, Universidad de Deusto, Bilbao, 1996, págs. 139-152. 
analizaría también las características iconográficas y estilísticas de estas pinturas, incluyendo un estudio de sus autores, cronologías y temáticas principales.

Aunque abundan las publicaciones acerca del origen de la escuela de pintura novohispana, los artistas que la integran y las iconografías más repetidas, no sucede lo mismo con las pinturas novohispanas localizadas en España. Aún así, contamos con ciertos estudios que tratan el tema, cada vez más frecuentes y exhaustivos. Sin embargo, es escasa la bibliografía relativa al proceso de llegada de esas pinturas. La dificultad estriba en que la mayor parte de los datos que abordan esta cuestión figuran en documentos de la época custodiados en distintos tipos de archivos - históricos, parroquiales, de protocolos notariales...-, lo que exige una búsqueda minuciosa.

La impronta europea en el arte americano es un hecho irrefutable. La llamada conquista espiritual dio lugar a la construcción de gran número de centros de culto y a la difusión de un arte religioso trasunto del español. La aparición en el virreinato de los primeros artistas europeos hacia mediados del siglo XVI es un acontecimiento bien documentado. Hasta entonces la actividad artística estaba en manos de los indígenas instruidos por los frailes españoles en los conventos y escuelas dependientes de los templos que transmitían las corrientes artísticas europeas. ${ }^{2}$ Producían una pintura mural de gran carácter didáctico inspirada en los grabados europeos, que eran copiados evitando introducir cualquier innovación y ajustándose fielmente a los cánones de representación estipulados por las autoridades eclesiásticas. "Porque han salido grandes pintores después que vieron las muestras e imágenes de Flandes e Italia que los Españoles han traído". ${ }^{3}$ Tal y como narran las crónicas de los frailes, los indios demostraron una gran habilidad para el arte de la pintura, lo que llegó a suponer una dura competencia para los pintores europeos que derivó en la creación del gremio de pintores de la ciudad de México.

La llegada de artistas europeos al virreinato y el envío de pinturas europeas constituyeron la primera referencia, dando pie al desarrollo de la pintura virreinal. Se trataba de obras bastante apreciadas, aunque no constituyeran un fiel reflejo de la pintura elaborada en sus lugares de ori-

2 La escuela más importante fue la de San José de los Naturales, fundada por fray Pedro de Gante en el Convento de San Francisco el Grande de la ciudad de México.

3 Motolinía, fray Toribio de: Historia de los indios de Nueva España, Clásicos Castalia, Edición de Georges Baudot, Madrid, 1985, págs. 356-357. 
gen. ${ }^{4}$ También diferían en cuanto al nivel y al lenguaje pictórico requerido. Además, existían una serie de condicionantes impuestos por el traslado, por lo general costoso e inseguro. Esto determinó que fuera una pintura importada al por mayor, de escasa calidad técnica, con un valor eminentemente devocional. Las pinturas eran tratadas como simples productos enviados en muchos casos a través de mercaderes, destinadas a un público mayorista poco exigente. Estos envíos eran perfectamente registrados.

La ciudad que controlaba este comercio artístico era Sevilla, de donde partían las flotas trasatlánticas. Era la localidad más poblada del reino de Castilla y ofrecía las ventajas de ser un puerto interior. Fue tal el auge que alcanzó este intercambio a comienzos del siglo XVII, que prácticamente todos los maestros que trabajaban en ella negociaron con las Indias. ${ }^{5}$

El puerto de Veracruz, el más antiguo e importante del virreinato, enlazaba América con Europa. A medida que arraigaba la colonización y se organizaba el virreinato, el transporte de pinturas tuvo lugar en sentido inverso. En este caso, tanto los responsables como el objetivo perseguido diferían de los anteriores. Estos no eran ya pintores que buscaban hacer negocio en las Indias ni instaurar unos patrones estéticos, sino que, por el contrario, las pinturas llegaban de manera aislada y formando parte en la mayoría de los casos de ajuares personales.

Para entender en su totalidad lo que implica su presencia en nuestro país es preciso hacer algunas alusiones iconográficas. Hay que recalcar que la mayoría de las obras pictóricas que se produjeron en Nueva España tenían una función educadora y propagandística cuya principal pretensión era difundir el fervor religioso. Las peculiares circunstancias que presentaba la población del virreinato exigían además una cualidad integradora y que permitiera su fácil comprensión. En este sentido, la imagen barroca fue el instrumento ideal para las estrategias colonizadoras de la Iglesia y el Estado. Además de ser un objeto de culto, también poseía connotaciones políticas, alegóricas o mitológicas.

Las iconografías representadas provenían en gran medida de la pintura española, aunque pronto se hicieron patentes ciertas peculiaridades. A

4 El historiador José Rogelio Ruiz Gomar afirma que el artista rondeño Alonso Vázquez, pese a su breve paso por el virreinato, dejó "fuerte impronta que el tiempo no ha logrado borrar". Ruiz Gomar, José Rogelio: "Las pinturas atribuidas a Alonso Vázquez en México", Anuario de Estudios Americanos, XXXVIII, Escuela de Estudios Americanos, Sevilla, 1981, págs. 659-660.

5 Serrera, Juan Miguel: "Zurbarán y América", en VV.AA.: Zurbarán. Catálogo de la exposición, Ministerio de Cultura, Banco Bilbao-Vizcaya, Madrid, 1992, pág. 71. 
finales del siglo XVI surgió un tipo de imagen que explotaba los milagros y las nuevas advocaciones que estos generaban. El virreinato se llenó de devociones autóctonas, de santos nativos y vírgenes "no blancas" que encarnaban a la perfección los valores indígenas y constituían un signo de identidad cultural. Muchas imágenes novohispanas como San Miguel del Milagro, la Virgen de Ocotlán, el Cristo de Chalma o la Virgen de la Macana habían protagonizado hechos milagrosos en los que un indio actuaba de intermediario.

Pero el culto profesado a la Virgen de Guadalupe superó a todos estos, constituyendo un auténtico lazo de unión entre las distintas etnias y clases sociales. Aunque la devoción a su homónima de Extremadura se trasplantó a América durante los primeros tiempos de la conquista, la de México ostenta orígenes propios. Los misioneros trataron de vincular la historia mexicana a la europea, utilizando la cualidad unificadora de la Virgen de Guadalupe para lograr sus fines evangelizadores, pues además de ser una figura nativa y popular, constituía el principal exponente de la religión católica en Nueva España. El empeño de los indígenas por distinguirla de la extremeña puede considerarse el primer paso para el surgimiento de la conciencia nacional mexicana. Muchos escritores como Luis Lasso de la Vega, Francisco de Florencia, Miguel Sánchez o Miguel Cabrera respaldaron su carácter milagroso y genuinamente novohispano, tratando de convertirla en un símbolo de los valores indígenas y el sentimiento patriótico. ${ }^{6}$

A tenor de la inmensa devoción de la que gozó, no es de extrañar que fuera abundantemente plasmada por los artistas novohispanos. De hecho fue sin parangón la imagen más representada en los talleres virreinales. Los pinceles más prestigiosos como Juan Correa, Cristóbal de Villalpando o Miguel Cabrera dedicaron a la patrona de México una parte fundamental de su repertorio.

Su tipo iconográfico nada tiene que ver con el de la virgen extremeña. Su modelo es apocalíptico, derivado del de la Inmaculada Concepción. Se acuñó tomando como referencia la imagen que, según la tradición, había quedado milagrosamente impresa en la túnica de un indio llamado Juan Diego. La Virgen aparece en todas sus representaciones posada sobre un cúmulo de nubes, rodeada de rayos, con una cabeza de querubín a sus

6 Según recoge Rafael Montejano, en el siglo XVII se escribieron treinta obras destinadas a ensalzar la aparición de la Virgen de Guadalupe, y en el siglo XVIII esta cifra ascendió a ciento cincuenta. Montejano Aguiñana, Rafael: "Bibliografía guadalupana”, Ábside, Revista trimestral cultural mexicana, $t$ XIII, Jus, México, 1949, pág. 355. 


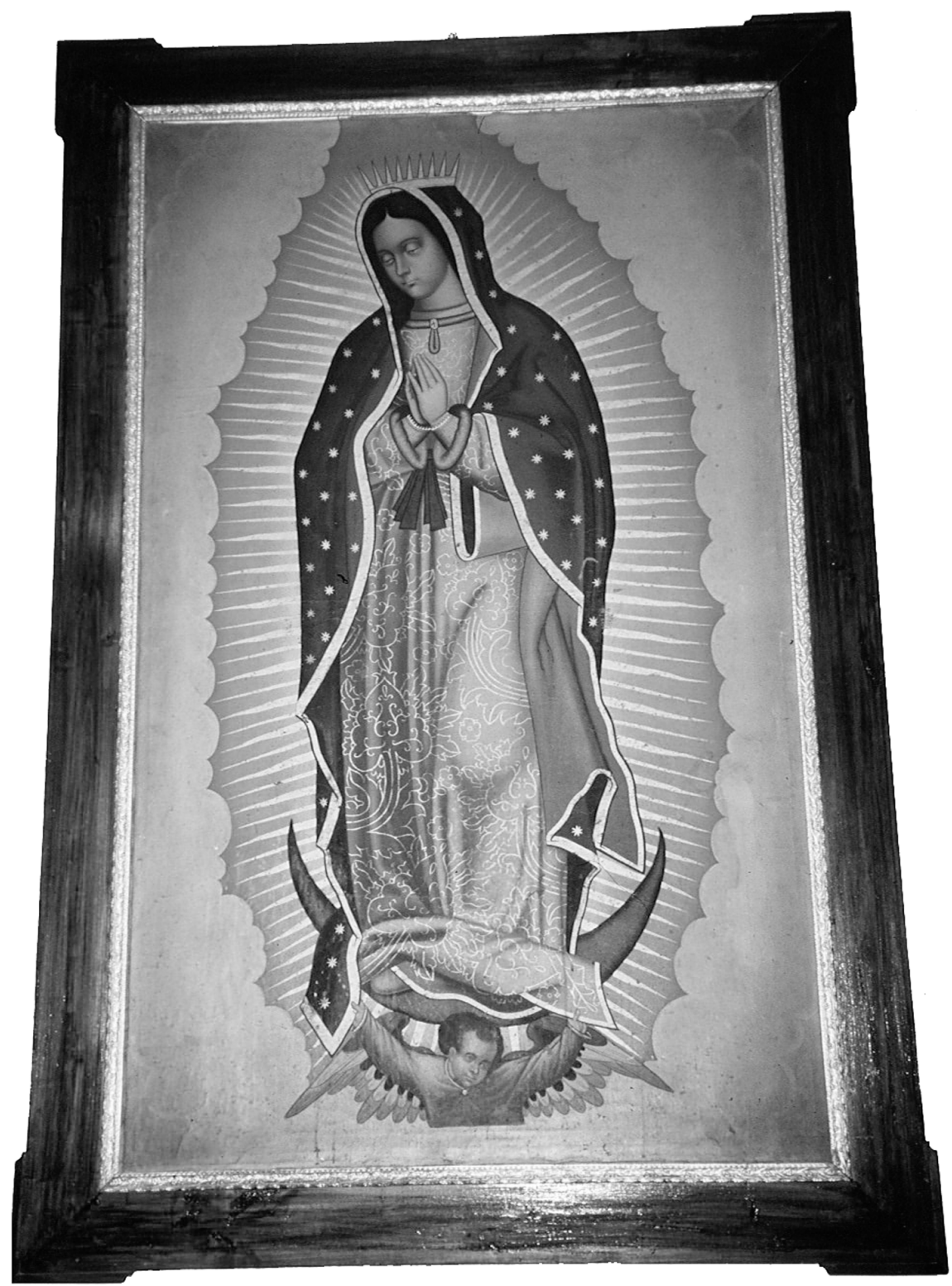

1. Virgen de Guadalupe. Sacristía de la iglesia del Convento de las Comendadoras de Santiago de Granada. Anónimo, siglo XVII, óleo sobre lienzo. 
pies y la tez morena propia de los indios. La variante más repetida es la que la muestra rodeada por cuatro medallones que narran la secuencia del milagro.

Respecto a la localización de las pinturas novohispanas en España, en la mayoría de los casos responde a motivaciones concretas: "Resulta obvio que los intereses del comercio trasatlántico ya jugaban buena parte en este tráfico de imágenes devocionales, amén que servían como talismanes para alcanzar puerto seguro. De allí que a estas ciudades estratégicas fueran a dar las primeras o las más abundantes imágenes remitidas desde América, ya fuese para los templos, o simplemente para ornar los oratorios privados de los mismos "indianos".

La causa más influyente fue sin duda la cercanía al mar. Por ello en lugares como Sevilla, Cádiz, o las Islas Canarias se verifica una significativa muestra de pintura virreinal. Dada su privilegiada situación estratégica, las Islas Canarias desempeñaron un papel decisivo en las relaciones con América. Desde el primer viaje de Colón, todos los barcos hacían escala técnica en ellas. Otro lugar de gran actividad fue el puerto de Málaga, que poseía grandes cualidades para el comercio y desde 1529 obtuvo el derecho a comerciar con el Nuevo Mundo.

Otro de los factores a tener en cuenta es la actividad religiosa. Ciertas zonas se caracterizaron por la cantidad de instituciones eclesiásticas, algunas especialmente conectadas con el virreinato de Nueva España. En Salamanca, por ejemplo, dos hechos contribuyeron poderosamente a la llegada de pinturas virreinales: la existencia de una prestigiosa universidad donde se formaba la elite de los funcionarios, y la ubicación de conventos de las órdenes religiosas más importantes. En el reino de Jaén constatamos una situación semejante. Poseía un predominio de tierras realengas y su Iglesia gozaba de gran renombre. Además, la Universidad de Baeza destacó notablemente en el plano cultural.

Hubo lugares estrechamente relacionados con el descubrimiento como Extremadura o el litoral de Huelva. También fueron muchos los exploradores y descubridores castellano-leoneses que tomaron parte en el primer viaje de Colón. Las provincias de Valladolid, Palencia, Segovia, Ávila o Burgos, fundamentalmente agrícolas y algunas bastante deprimidas, acusa-

7 Cuadriello, Jaime: "La propagación de las devociones novohispanas: las Guadalupanas y otras imágenes preferentes”, Discursos en el Arte. XV Coloquio Internacional de Historia del Arte, Instituto de Investigaciones Estéticas, México, 1991, pág. 262. Este artículo es probablemente el más detallado de cuantos se han publicado acerca de la pintura novohispana en España. 
ron una fuerte emigración ultramarina. También localidades como las de Navarra, el País Vasco o Cantabria tuvieron una gran tradición migratoria.

Aunque por unas causas u otras casi todas las regiones españolas mantuvieron algún tipo de contacto con América, Andalucía fue la más ligada al virreinato. De hecho, la mayor parte de los descubridores y primeros colonizadores de América fueron andaluces. Los vínculos con el Nuevo Mundo fueron mucho más estrechos en la zona occidental, pues las ciudades de Sevilla y Cádiz desempeñaron un relevante papel en el tránsito de pasajeros y las relaciones comerciales con América.

En un primer momento, Sevilla centralizó todo el comercio y el tráfico indiano. Desde la creación en 1503 de la Casa de la Contratación se convirtió en "Puerto y Puerta de Indias", produciéndose un gran incremento del tráfico marítimo con América. En 1529 perdió su prerrogativa de puerto único, y el 12 de mayo de 1717 la Casa de la Contratación trasladó su sede a Cádiz, dando lugar con ello al fin del monopolio sevillano.

Según el historiador Francisco Morales Padrón, los inventarios de casas y testamentos señalan el cosmopolitismo de esta ciudad y la constante presencia americana. ${ }^{8}$ El investigador sevillano Joaquín González Moreno recoge unas trescientas de las pinturas de la Virgen de Guadalupe que se conservan en España, y afirma que en Sevilla residen más de mil. Esta provincia es la principal depositaria de pintura novohispana en nuestro país. "El Guadalquivir, río terminal en la ruta entre España y Méjico, era el camino por donde entraban a la Península las guadalupanas. Las ciudades y pueblos que se levantaban en sus orillas, conservan los mejores lienzos, tablas, cobres y grabados, traídos por los misioneros o seglares que regresaban del virreinato de Nueva España".

Innumerables ejemplos acreditan el fervor hacia la patrona de México en Sevilla y su entorno. Uno de los más representativos es el Hospital de Nuestra Señora de Guadalupe, el primer foco de devoción guadalupana en Andalucía. Fue fundado por don Fernando Enríquez de Ribera, III duque de Alcalá de los Gazules, con una licencia otorgada por el obispo de Roma. Era un hospital de pobres destinado a los centenares de enfermos y mendigos que atestaban las orillas del Guadalquivir pidiendo limosna a los comer-

8 Morales Padrón, Francisco: Andalucía y América, Arguval, Málaga, 1992, pág. 87.

9 González Moreno, Joaquín: Iconografía guadalupana en Andalucía, Junta de Andalucía, 1991, Jerez de la Frontera, pág. 11. Este investigador realizó un exhaustivo análisis de la pintura guadalupana situada en la comunidad andaluza, abarcando además obras localizadas en otras regiones españolas. Su criterio de ordenación, al igual que el de Jaime Cuadriello, es el iconográfico. 
ciantes y poderosos que participaban del comercio indiano. La advocación probablemente tenga que ver con la devoción que tanto su padre, don Payo de Ribera, como su abuelo profesaban a la Virgen de Guadalupe. ${ }^{10}$ Además, en esta ciudad fue frecuente la creación de ermitas, capillas y altares bajo el patrocinio de la Guadalupana. El Padre Antonio de Solís informaba de que el padre Manuel de la Peña erigió en 1735 dos nuevos altares en la Capilla de la Anunciación de la Casa Profesa de la Compañía de Jesús en Sevilla — actual Capilla de la Universidad—, uno a Nuestra Señora de Guadalupe de México y otro a San Juan Francisco Regis. ${ }^{11}$

Entre los personajes sevillanos conocidos por su devoción guadalupana, podemos mencionar a Antonio M. ${ }^{a}$ Bucarelli y Ursúa, virrey de Nueva España, quien dispuso en su testamento que lo enterraran en la Colegiata de Guadalupe en México. ${ }^{12}$

La popularidad de esta advocación también queda patente en el ajuar de sevillanos avecindados en México como el maestro platero Antonio de Salinas. Esto puede comprobarse en la carta de dote otorgada a favor de doña Cecilia Teresa de la Cruz, su futura esposa, fechada el 27 de febrero de 1744. Entre los bienes recibidos se cuentan varias pinturas, entre ellas "un lienso de Nuestra Señora de Guadalupe de dos y quarta de alto y una media de ancho con las cuatro aparisiones". ${ }^{13}$

Se sabe que muchos eclesiásticos trajeron o enviaron pinturas novohispanas. Según cuentan sus biógrafos, el ilustre sevillano fray Payo de Ribera, arzobispo y virrey de Nueva España, a su regreso sólo traía un lienzo de la Virgen de Guadalupe, de la que era un gran devoto. ${ }^{14}$ Por otro lado, el sevillano fray Pedro de los Reyes regía a comienzos del siglo XVIII el obispado de Yucatán y no sería de extrañar que hubiera enviado a otros religiosos de su orden, familiares o amigos alguna representación guadalupana.

Aunque a menor escala, Cádiz fue también uno de los principales enclaves portuarios durante la época virreinal. A mediados del siglo XVI adquirió protagonismo en el tráfico americano, pasando de ser un simple antepuerto complementario a Sevilla a sustituirla como capital de la carrera de Indias. A ello contribuyó la creación del Juzgado de Indias, uno de los

10 Ibídem, pág. 47.

11 Solís, Antonio de: Los dos espejos, historia de la Casa Profesa de los jesuitas en Sevilla, Sevilla, 1755.

12 Castillo Piña, José: Tonantzin. Nuestra madrecita la Virgen de Guadalupe, México, 1945, pág. 73.

13 México. Archivo de Notarías, n. ${ }^{\circ}$ 133, año 1742. Escribano Juan José de la Cruz Aguilar.

14 González Moreno: Iconografía guadalupana en Andalucía..., pág. 57. 
principales organismos de jurisdicción americanista. Tampoco en este caso faltan los ejemplos de devoción a la virgen mexicana. Como consecuencia de ello, Cádiz es la segunda provincia española — después de Sevilla— con mayor número de obras de iconografía guadalupana. En palabras del jesuita Francisco de Florencia, "en Cádiz, en Sevilla y en todas partes de católicos que tiene comercio Nueva España, es tan conocida, tan venerada y aplaudida esta santa imagen, que apenas hay casa en que no la tengan". ${ }^{15}$ Como dato significativo podemos mencionar que la Virgen de Guadalupe de México es la patrona del pueblo gaditano de Algar. Este inusual patronazgo se debe al señor Domingo López de Carvajal, vizconde de Carrión y marqués de Atalaya Bermeja, gallego avecindado en El Puerto de Santa María—Cádiz-, quien fundó la villa de Algar en el último cuarto del siglo XVIII en cumplimiento de una promesa realizada a la virgen mexicana durante la travesía de regreso de Nueva España. ${ }^{16}$ Muchos gaditanos tanto eclesiásticos como seglares vinculados con el virreinato trajeron pinturas novohispanas. Según el inventario de la colección artística del clérigo don Gaspar Ximénez Parrado, uno de los diecisiete cuadros de temática religiosa que poseía representaba a Nuestra Señora de Guadalupe. ${ }^{17}$ Un caso similar es el de don Vicente Pulciani, hombre ilustre fundador de diversas órdenes religiosas, que contaba entre sus bienes con varias láminas con figuras de santos, incluyendo a la Virgen de Guadalupe. ${ }^{18}$

Otro foco del litoral andaluz donde no tardó en irradiarse el fervor guadalupano fue Huelva. Don Francisco Martín Olivares, un comerciante onubense que se enriqueció en México, quiso, en señal de agradecimiento, que una imagen de la Virgen de Guadalupe figurase en un altar junto a la Virgen de la Cinta, patrona de esta provincia. Un poder otorgado en México en 1756 facultaba al sacerdote don Andrés Valiente a instituir una fiesta en honor de la Virgen mexicana: “...así mismo se agrege otra memoria a Nuestra Señora de Guadalupe, cuya imagen se venera a solicitud y devoción de dicho D. Francisco en la expresada ermita, en la testera de la nave de la epístola, para todo lo cual ha remitido la cantidad de mil quinientos treinta y

15 Florencia, Francisco de: La Estrella del Norte de México. Edición del doctor Agustín de La Rosa, Original impreso en 1688 en la Imprenta Benavides, México, 1688.

16 Moreno, Salvador: "Guadalupanismo mexicano en Cádiz", Cádiz Iberoamérica, n. ${ }^{\circ} 2$, Universidad de Cádiz, Cádiz, 1984, págs. 28-29. Además de ilustrar acerca de este hecho, este investigador informa sobre la presencia de varias obras guadalupanas localizadas en la provincia gaditana.

17 Morgado García, Arturo: Iglesia y sociedad en el Cádiz del siglo XVIII, Universidad de Cádiz, Cádiz, 1989, pág. 52.

18 García Fernández, M. ${ }^{a}$ Nélida: Burguesía y toga en el Cádiz del siglo XVIII. Vicente Pulciani y su biblioteca, Universidad de Cádiz, Cádiz, 2000, págs. 30-31. 


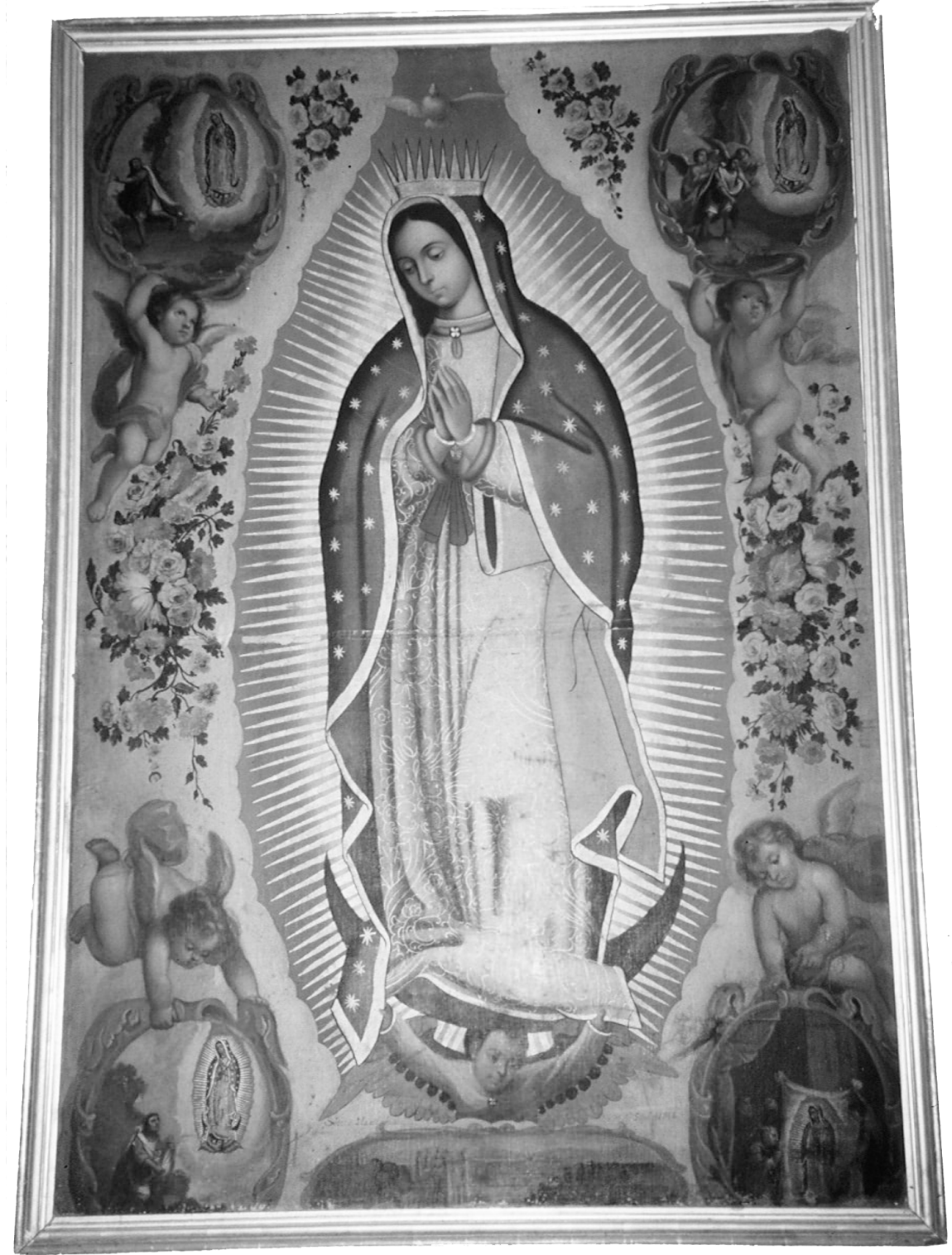

2. Virgen de Guadalupe. Sacristía de la Iglesia de San Antonio de Cádiz. Anónimo, 1748, óleo sobre lienzo. 
cuatro pesos en varias ocasiones...”. La Virgen de Guadalupe, cuyo altar fue trasladado a la nave del evangelio, preside hoy día una capilla. ${ }^{19}$

Resulta evidente que el hecho que mejor explica la llegada de pinturas es la presencia de un gran número de españoles que arribaron a tierras novohispanas. Los catálogos de pasajeros a Indias, constituidos a base de licencias para embarcar en las que consta el nombre, la procedencia y la profesión del personaje, son una fuente primordial para conocer la emigración española a América. Aunque muchos de ellos poseían un nivel social elevado, la posesión de pinturas no fue un fenómeno exclusivo de estos sectores.

Entre las causas que intervinieron podemos aludir a la alta cifra de funcionarios españoles que se habían establecido en el virreinato y eran los principales poseedores de obras de arte. A veces, a su regreso a España, traían esas pinturas consigo para decorar sus domicilios, regalar a sus allegados, o donar a instituciones religiosas de su localidad natal. Este tipo de obsequios respondían sobre todo al deseo de dar a conocer en su lugar de origen a la virgen o el santo al que se habían encomendado en América y que a menudo relacionaban con la fortuna adquirida en esas tierras.

Además de su valor básicamente religioso y en algunas ocasiones artístico, al tratarse de iconografías desconocidas en España había que añadirles un componente de exotismo. De hecho, las obras novohispanas más demandadas eran las que incluían en su temática algún elemento diferenciador, lo que implicaba que los responsables de estos envíos actuaban desde el virreinato. La pintura perteneciente a la "escuela mexicana" adquirió una personalidad propia de gran atractivo para el gusto español. Entre los géneros que alcanzaron mayor difusión se encuentran los "enconchados", que incluía incrustaciones de concha de nácar según una técnica oriental. ${ }^{20}$ En España se conservan algunas representaciones, la mayoría situadas en el Museo de América de Madrid. Una variedad típicamente mexicana que también gozó de gran aceptación fue la pintura "de castas", que mostraba a las distintas

19 González Moreno: Iconografía guadalupana en Andalucía..., págs. 69-70.

20 La primera noticia acerca de enconchados localizados en España la ofreció don Antonio Ponz refiriéndose a varias tablas que trataban el tema de la conquista de México y las batallas de Alejandro Farnesio, propiedad de los duques del Infantado. Ponz, Antonio: Viaje por España, Edición facsímil, Madrid, 1972. Un estudio publicado por Santiago Silva explicaba la técnica de manufactura: sobre un soporte de madera, forrada o no de tela de lino, se añadía una base de yeso sobre la que se pegaban trozos de nácar. Por último se aplicaba la pintura, que podía incluir polvo de oro. Silva, Santiago J. de: Algunas consideraciones sobre las pinturas enconchadas, Museo Nacional de Historia, Castillo de Chapultepec, México, 1976. Uno de los trabajos más recientes acerca de esta técnica artística es el publicado por los historiadores Serrera, Juan Miguel, y García Sáiz, María Concepción: “Aportaciones al catálogo de 'enconchados"”, Cuadernos de Arte Colonial, $n .{ }^{\circ}$ 6, Museo de América, Madrid, 1990, págs. 55-87. 
razas producto del mestizaje poblacional del virreinato. También el Museo de América cuenta con varias series como las realizadas por Miguel Cabrera.

Otra causa de la buena aceptación de estas pinturas era el gusto por ciertas devociones americanas que se habían popularizado, en especial la Virgen de Guadalupe. Según el historiador Charles Gibson, "el éxito de la devoción a la Virgen de Guadalupe se debe sobre todo a que se trata de un fenómeno indígena". ${ }^{21}$

Innumerables testimonios dan fe de la expansión de esta advocación entre la población española. En 1740 un grupo de españoles que habían residido en el virreinato se reunieron en la Iglesia de San Felipe Neri de Madrid ante una pintura de la Guadalupana para fundar una congregación en su honor. Fue respaldada por Felipe V y confirmada por una bula papal de Benedicto XIV en 1754. ${ }^{22}$

Según cuenta el jesuita Francisco de Florencia, en una fecha tan temprana como 1654 fue nombrado consejero del Consejo de Indias el oidor de Granada y visitador en Nueva España don Pedro de Gálvez, a donde llevó una pintura de la Virgen de Guadalupe. ${ }^{23}$

El sector eclesiástico fue uno de los que más colaboró en la llegada de pinturas. Las diversas órdenes religiosas que desarrollaron en el virreinato su labor evangelizadora trajeron consigo o mandaron pinturas de la Guadalupana a los conventos e iglesias de su misma orden o a los de su localidad natal con una función esencialmente piadosa.

La orden franciscana fue la que introdujo en España la devoción a la Virgen de Guadalupe. Tal y como narra fray Esteban Anticolí, en los conventos franciscanos de Valladolid, Palencia, Segovia, Rioseco, Villalvin y Peñafiel existieron altares guadalupanos. ${ }^{24}$ Don Mariano de Echeverría y Veytia relata que visitó la iglesia del Convento de San Francisco de Valladolid, encontrando junto a la reja de la Capilla Mayor un lienzo de la Virgen de Guadalupe de gran tamaño pintado por el artista novohispano Juan Correa en 1667.25

21 Gibson, Charles: Los aztecas bajo el dominio español (1519-1810), Siglo XXI, México, 1967, págs. 135-136.

22 González Moreno: Iconografía guadalupana en Andalucía..., págs. 40-41.

23 Florencia: La Estrella del Norte de México..., pág. 196.

24 Anticolí, Esteban: Historia de la Aparición de Nuestra Señora de Guadalupe, desde 1531 hasta 1895, México, 1897, t. II, pág. 260.

25 Fernández de Echeverría y Veytia, Mariano: Baluartes de México. Relación histórica de las cuatro sagradas y milagrosas imágenes de Nuestra Señora, la Virgen María, que se veneran en la muy noble, leal e imperial ciudad de México, capital de la Nueva España. Alejandro Valdés, México, 1820 (1778). 
En la mayoría de los casos el propósito era puramente devocional, y en casi todos se centraba en la figura de la virgen mexicana. Las remisiones de pinturas se incrementaron a partir de 1670 debido a la proliferación de talleres especializados, pero sobre todo a la propaganda del clero crio1lo. El cardenal leonés Francisco Antonio de Lorenzana fue arzobispo de México y conocido por su devoción a la Virgen de Guadalupe. ${ }^{26}$

El 6 de septiembre de 1756 el dominico granadino fray Alonso de Montúfar pronunció un sermón en honor de la Virgen de Guadalupe en el Santuario del Tepeyac - México-, convirtiéndose en uno de los más fervientes difusores del culto guadalupano.

Numerosos clérigos de diferentes rangos contribuyeron a la difusión guadalupana. Muy a menudo ésta se materializaba en la donación de pinturas a recintos sagrados, con lo que se pretendía introducir en nuestro país advocaciones indianas que pasaban a figurar junto a las ya conocidas, dotando a nuestros espacios de culto de un componente nuevo, con connotaciones indígenas, producto del sincretismo religioso.

En líneas generales seguían unos patrones estéticos parecidos y se trataba de obras corrientes, anónimas, en las que primaba el valor simbólico. Casi siempre el destino coincidía con la localidad natal del donante. Por ejemplo, la pintura de la Virgen de Guadalupe obra de Juan Rodríguez Juárez que se ubica en la Parroquia de Santa María de Viana -Pamplona - fue donada en 1720 por el arzobispo de México Juan Pérez de Lanciego, de donde era originario. ${ }^{27}$ El sacerdote don Pedro García Maté, secretario del arzobispo y virrey don Payo Manrique, fue el autor de la donación de un lienzo de la Virgen de Guadalupe y otro de la Inmaculada Concepción a la iglesia parroquial de Quintanaloranco - Burgos- en $1681 .{ }^{28}$ Se sabe que fray Manuel de la Vega y Calvo, franciscano que fue

26 Bonet Correa, Antonio: "El Cardenal Lorenzana y el arte mexicano", en VV.AA.: Relaciones artísticas entre la Península Ibérica y América. Actas del V Simposio Hispanoportugués de Historia del Arte. Valladolid, 11-13 de Mayo de 1989, Universidad de Valladolid, Valladolid, 1989, págs. 43-46.

27 Echeverría Goñi, Pedro Luis: "Mecenazgo y legados artísticos de indianos en Navarra", Segundo Congreso General de Historia de Navarra, Universidad de Pamplona, Pamplona, 1991, pág. 184.

28 Ibáñez Pérez, Alberto: "Relaciones artísticas entre Burgos y América. La Virgen de Guadalupe en Burgos", en VV.AA.: Relaciones artísticas entre la Península Ibérica y América. Actas del V Simposio Hispanoportugués de Historia del Arte. Valladolid, 11-13 de Mayo de 1989, Universidad de Valladolid, Valladolid, 1989, pág. 140. Este investigador pone de relieve que a pesar de la cantidad de pinturas guadalupanas que se conservan en esta provincia, no se conoce ni una sola capilla dedicada a la Virgen de Guadalupe. Recoge centenares de representaciones guadalupanas y ofrece datos acerca de sus orígenes. 
comisario general de Indias, patrocinó varias obras de la Iglesia parroquial de San Andrés de Valladolid y regaló a dicha parroquia un lienzo de la Virgen de Guadalupe. ${ }^{29}$ Al parecer, la representación de la Virgen de Guadalupe que se custodia en la Iglesia de San Ildefonso de Jaén fue un legado de fray Juan Bautista Moya. ${ }^{30}$ Asimismo, en la Catedral de Santiago de Compostela se ubica una representación de la Virgen de Guadalupe pintada sobre lámina de cobre por Juan Patricio Morlete Ruiz que fue un donativo hecho por el canónigo Losada en $1770 .{ }^{31}$

Bastantes conventos y monasterios relacionados con el virreinato a través de alguno de sus religiosos recibieron pinturas mexicanas. El sacerdote mallorquín don José Fornani fue nombrado rector del antiguo Convento de San Felipe Neri de Palma tras una estancia en el virreinato, donde hizo levantar un altar con la imagen de la Virgen de Guadalupe. En el convento se custodiaban cuatro lienzos de la Virgen de Guadalupe, uno de los cuales es mencionado en su testamento, en el que queda constancia de su profunda devoción por la Guadalupana. ${ }^{32}$ Consta que un lienzo de la Virgen de Guadalupe firmado por Juan Correa que se encuentra en el Convento de Agustinas Recoletas de Pamplona lo cedió el capellán don Miguel de Ostíbar entre 1677 y $1731 .^{33}$

A menudo estas donaciones las efectuaban algún miembro de la orden al adherirse a ella. Según informan los investigadores Elisa Vargas Lugo y José Guadalupe Victoria, una de las pinturas de la Virgen de Guadalupe

29 Andrés Ordax, Salvador: "Arte americanista en Castilla y León”, en VV.AA.: Catálogo de la Exposición celebrada en Valladolid, Iglesia de la Magdalena, 11 de Noviembre-11 de Diciembre de 1992, Junta de Castilla y León, Valladolid, 1992, pág. 42. Este catálogo constituye una de las obras más completas acerca de la pintura novohispana localizada en España, aunque se ciñe únicamente a esta comunidad.

30 Ortega y Sagrista, Rafael: "Una reproducción de la Virgen de Guadalupe en la Iglesia de San Ildefonso de Jaén", Senda de los Huertos, pág. 18. Véase Molina Martínez, Miguel: "El Santo Reino, centro de irradiación de fe", en VV.AA.: Reino de Granada. V Centenario. La aventura americana, Diario Ideal, Granada, 1992, t. III, pág. 112.

31 Taín Guzmán, Miguel: "La cajonería barroca de la catedral de Santiago de Compostela. Muebles ebúrneos al servicio del Apóstol”, en VV.AA.: Actas del Congreso Barroco Iberoamericano. Territorio, Arte, Espacio y Sociedad. Sevilla, 8 al 12 de Octubre de 2001, Universidad Pablo de Olavide, Ediciones Giralda, Sevilla, 2001, pág. 747.

32 Sebastián López, Santiago: "Iconografía guadalupana en Palma de Mallorca", Anales del Instituto de Investigaciones Estéticas, $n^{\circ}$ 44, Universidad Nacional Autónoma de México, México, 1975, págs. 137-143.

33 Heredia Moreno, María del Carmen; Orbe Sivatte, Mercedes, y Orbe Sivatte, Antonia: Arte hispanoamericano en Navarra, Gobierno de Navarra, Pamplona, 1992, pág. 214. Esta obra ofrece un interesante compendio de la abundante pintura guadalupana y de otras iconografías novohispanas ubicadas en Navarra. Además, en muchos casos incluye datos sobre los personajes que las trajeron. 


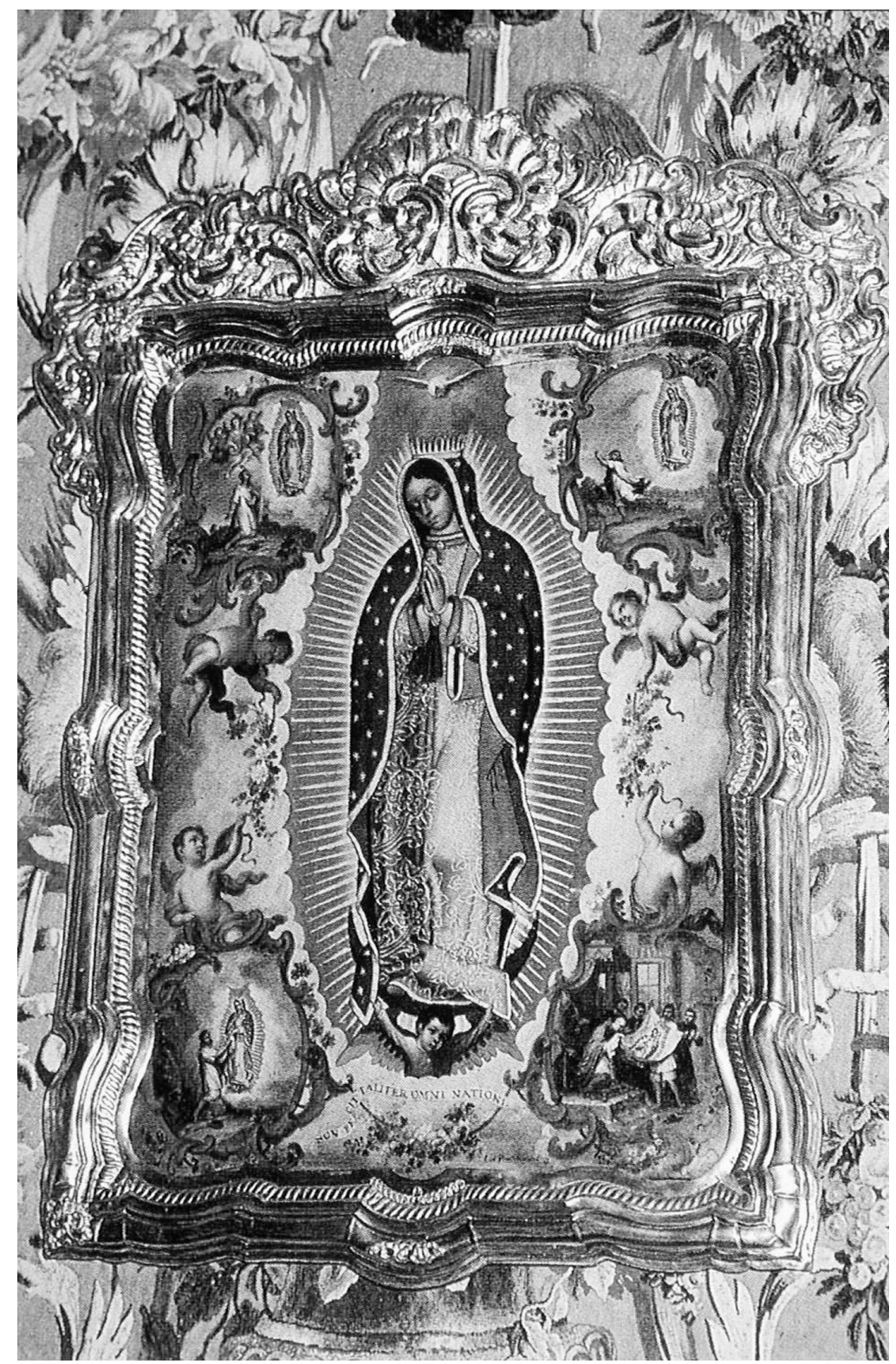

3. Virgen de Guadalupe. Sala Capitular de la Catedral de Santiago de Compostela (La Coruña). Juan Patricio Morlete Ruiz, 1770, óleo sobre lámina de cobre. 
conservadas en el Convento de Santa Paula de Sevilla, obra de Juan Correa fechada en 1712, fue donada por la superiora de este convento, sor Cristina de Arteaga, hija del duque del Infantado, cuando ingresó en la comunidad. ${ }^{34}$

Parece ser que la pintura de la Virgen de Guadalupe que se halla en el Colegio de la Enseñanza de Tudela - Pamplona—, obra de Antonio de Torres, fue un regalo efectuado en 1734 por Sor Ignacia de Azlor, hija de los marqueses de Aguayo y priora del Convento de la Compañía de María en México. ${ }^{35}$

Estos personajes y otros, seglares, conocidos como "indianos", reedificaron templos, financiaron capillas y fundaron mayorazgos. Junto con las pinturas eran frecuentes los obsequios de cálices, atuendos litúrgicos, relicarios... En un principio, el término "indiano" servía para designar a todo español que se establecía en las colonias americanas, pero su aplicación más popular se refiere a los que, tras pasar una larga temporada allí, regresaban a su tierra de origen más o menos enriquecidos y ejercían labores de mecenazgo artístico. A su vuelta solían ser mirados con recelo, por lo que donar objetos de culto respondía en muchos casos a un deseo de reconocimiento social. El tipo de donación dependía del lugar y el estatus socioeconómico del indiano. La mayor parte de ellas se hacían por vía testamentaria. También era frecuente la creación de patronatos, que consistía en la cesión de un espacio dentro de una iglesia a una familia noble. Algunas veces, una misma familia que había mantenido conexión con el virreinato se convertía en mecenas de una zona y prolongaba su patronazgo durante generaciones.

En la mayoría de las ocasiones se trataba de militares o funcionarios con un buen nivel adquisitivo que habían desempeñado cargos relevantes en Nueva España. Con frecuencia donaron obras de arte, entre ellas pinturas, casi todas de temática guadalupana. Don Sebastián de Ulierte y Vergara, guardacuños y fiscal administrador de la Casa Real de la Moneda en México, ejerció labores de mecenazgo artístico en Belandia — Orduña, Guipúzcoa-, donde permanecen pinturas novohispanas.

En 1674, el capitán Jerónimo de Calatayud, residente en México, envió a Viana -Pamplona-, entre otros objetos, "un cajoncillo con tres imágenes de $\mathrm{N}^{\mathrm{a}} \mathrm{S}^{\mathrm{a}}$ de Guadalupe" ${ }^{36} \mathrm{El}$ historiador Antonio Casaseca apun-

34 Vargas Lugo, Elisa, y Victoria, José Guadalupe: Juan Correa. Su vida y obra. Catálogo, Universidad Nacional Autónoma de México, Instituto de Investigaciones Estéticas, México, 1994, t. II, primera parte, pág. 239.

35 Ibídem, pág. 216.

36 Labeaga, Juan Cruz: "Donaciones y otras benéficas de los indianos de Sangüesa y Viana", Príncipe de Viana, Anejo 13, Universidad de Pamplona, Pamplona, 1991, pág. 340. 
ta que la pintura de la Virgen de Guadalupe que se localiza en la Iglesia de San Pedro de Ciudad Rodrigo - Salamanca_- firmada por Juan Correa, probablemente sea una donación de los descendientes del capitán Juan Pacheco Maldonado. ${ }^{37}$ Asimismo, se sabe que el lienzo de la Virgen de Guadalupe que se encuentra en la Iglesia de Santa Catalina de Tacoronte - Tenerife-, atribuido a José de Páez, fue un legado devocional hecho hacia 1750 por el capitán José Espinosa Bethancourt. ${ }^{38}$ Otro ejemplo lo constituye la Virgen de Guadalupe pintada por Francisco Antonio Vallejo que se conserva en la Iglesia parroquial de Montemolín —Badajoz-, donada por don José Navarro del Coro. ${ }^{39}$

El investigador Domingo Martínez de la Peña apunta que la representación de la Virgen de Guadalupe que se ubica en la Iglesia de San Bartolomé de Tejina - Tenerife - puede estar relacionada con don Bernabé Fernández de Armas, natural de esta población y avecindado en Pinsandalo - Michoacán, México-, quien envió a esta parroquia objetos de culto a finales del siglo XVII. ${ }^{40}$ Se dispone de información que señala que un tal Juan Jiménez entregó al abad de la Iglesia de Muniain de la Solana -Pamplona - un ajuar litúrgico que incluía un lienzo de Nuestra Señora de los Remedios y otro de Nuestra Señora de Guadalupe. ${ }^{41}$

Aunque no es lo más habitual, a veces las pinturas poseían iconografías distintas a la guadalupana. La serie de doce lienzos sobre la vida de la Virgen - diez firmados por Correa y dos por Arellano- procedente de la Parroquia de San Pedro de Antequera - Málaga - y hoy conservada en el Museo de Bellas Artes de esa ciudad, fue donada por doña Cecilia

37 Casaseca Casaseca, Antonio: “Arte colonial en Salamanca”, en VV.AA.: Relaciones artísticas entre la Península Ibérica y América. Actas del V Simposio Hispanoportugués de Historia del Arte, Valladolid, 11-13 de Mayo de 1989, Universidad de Valladolid, Valladolid, 1989, págs. 59-67. Gracias a este artículo conocemos algunas de las guadalupanas situadas en iglesias y conventos salmantinos.

38 Cuadriello: "La propagación de las devociones novohispanas...”, pág. 284.

39 Esteras Martín, Cristina: "Presencia del arte novohispano en la Baja Extremadura", en VV.AA.: Hernán Cortés, hombre de empresa. Primer congreso de americanistas celebrado en Badajoz en 1985, Publicaciones de la Casa-Museo de Colón y Seminario Americanista de la Universidad, Valladolid, 1990, pág. 289. Esta historiadora da a conocer varias pinturas guadalupanas emplazadas en Extremadura.

40 Martínez de la Peña, Domingo: "Pinturas mejicanas del siglo XVIII en Tenerife", en VV.AA.: Anuario de Estudios Atlánticos. Madrid-Las Palmas, n. ${ }^{\circ}$ 23, Casa-Museo de Colón, Las Palmas, 1977, págs. 583-601. Esta investigación reúne múltiples pinturas novohispanas situadas en Tenerife, incluyendo guadalupanas y obras de otras iconografías.

41 Aramburu Zudaire, José Miguel: Vida y fortuna del emigrante navarro a Indias. Siglos XVI y XVII, Gobierno de Navarra, Pamplona, 1999, págs. 378 y 383. 
Blázquez de Lora, condesa de Colchado, quien la heredó de sus antepasados, uno de los cuales ocupó un importante puesto en el virreinato. ${ }^{42}$

La pintura de la Santísima Trinidad atribuida a Miguel Cabrera que se sitúa en la Parroquia de Santiago de Puente la Reina - Navarra - se supone un envío de don Miguel Francisco de Gambarte. ${ }^{43}$ Los lienzos de Santa Rosa de Viterbo y San Francisco de Asís que se hallan en la Iglesia del Real Santuario del Santísimo Cristo de La Laguna - Tenerife_- procedentes del Convento de San Miguel de las Victorias, fueron una donación hecha en 1691 por el capitán don Diego Pereira de Ocampo y Castro. ${ }^{44}$

En ocasiones excepcionales la llegada de una pintura a un espacio sagrado era fruto de la más pura casualidad. Esto sucedió con uno de los lienzos de la Virgen de Guadalupe que se custodian en el Convento de San José del Carmen —-las Teresas- de Sevilla. Su propietario, Guillermo Lathelise, al tener que marchar a Francia, se lo dejó a su "comadre" Micaela Aguilar para que lo vendiera, pero ésta, al no encontrar comprador, se lo entregó a doña Ana White, quien lo terminó donando al convento. ${ }^{45}$

La financiación de ermitas, capillas u obras de restauración de un templo fue una práctica común entre los indianos. La pintura de la Virgen de Guadalupe situada en la Ermita del Tránsito de Nuestra Señora de Icod - Tenerife - se relaciona con don Domingo de Torres y su esposa, fundadores de dicha capilla que mantenían constantes relaciones con las Indias. Su hermano, don Marcos de Torres, erigió la Ermita de Nuestra Señora de las Angustias de la misma localidad y trajo varias obras artísticas de Nueva España como los lienzos de la Sagrada Familia y la Virgen de Guadalupe que se sitúan en esa ermita. ${ }^{46}$

42 Clavijo García, Agustín: "La pintura colonial en Málaga y su provincia”, en VV.AA.: Andalucía y América en el siglo XVIII, Escuela de Estudios Hispano-Americanos, Sevilla, 1985, pág. 106. Este artículo da noticia acerca de bastantes obras novohispanas ubicadas en la provincia malagueña y sus autores.

43 Heredia Moreno, María del Carmen; Orbe Sivatte, Mercedes; Orbe Sivatte, Antonia: Arte hispanoamericano en Navarra..., pág. 218.

44 Negrín, Constanza: "El legado indiano de la familia Pereira de Castro en las Islas Canarias", en VV.AA.: Actas del XIII Congreso del Comité Español de Historia del Arte celebrado en Granada entre el 31 de Octubre y el 3 de Noviembre de 2000. Vol. II, Universidad de Granada, Granada, 2000, págs. 874-875.

45 Cano Navas, María Luisa: El convento de San José del Carmen de Sevilla, Universidad de Sevilla, Sevilla, 1984, págs. 144-145.

46 Fraga González, Carmen: "Nueva relación de pinturas mexicanas en Canarias”, en VV.AA.: $V$ Coloquio de Historia Canario-americana, Mancomunidad Provincial Interinsular de Cabildos de Las Palmas, Las Palmas de Gran Canaria, 1982, t. I, segunda parte, págs. 898-899. Esta publicación viene a completar la de Domingo Martínez de la Peña antes mencionada. 
Por otro lado, es preciso señalar que el aspecto devocional fue básico y la virgen mexicana ocupó un lugar privilegiado. Don Pablo Fernández Calderón, nacido en Carmona - Santander- y fallecido en México en 1791, le encargó a su sobrino don Fernando la edificación de la Ermita de Guadalupe "La Indiana", en el barrio de San Pedro de su pueblo natal, para la que envió un lienzo de la Virgen de Guadalupe ${ }^{47} \mathrm{El}$ indiano navarro don Juan Antonio Portillo y de la Sota, natural de Ontón, fundó a su regreso de México una ermita dedicada a la Virgen de Guadalupe ${ }^{48}$ Asimismo don Jerónimo Mateo Roiz de la Parra, natural de Cabezón de Liébana fallecido en México, creó la Ermita de la Virgen de Guadalupe de Acebaría - Santander-.$^{49}$ Por su parte, don Bartolomé Casabuena y Mesa, juez de Indias en Tenerife, construyó una capilla en la Iglesia de la Concepción de La Laguna - Tenerife - en 1725, en cuyo retablo se situaba una representación de la Virgen de Guadalupe..$^{50}$

También algunos religiosos fundaron capillas y ermitas que dotaron con piezas artísticas en sus lugares natales. El deán de la Iglesia Metropolitana de México Diego Guerra San Miguel, natural de Piña de Campos -Palencia—, compró una capilla en la Iglesia de San Miguel de su pueblo natal para la que mandó hacer un retablo con pinturas y a la que dotó de ornamentos y objetos para el culto, entre ellos "una tabla de pintura rica de nuestra Señora de los Angeles con su marco dorado... y un frontal de pintura al olio de la Asumpcion de Nuestra Señora". ${ }^{51}$ La Capilla del Santísimo Sacramento de la Iglesia Mayor de Nuestra Señora de la O de Sanlúcar de Barrameda — Cádiz - fue costeada por don Manuel de la Cueva y Aldana y el rico navegante don Enrique de Silva, quien además donó una pintura de la Virgen de Guadalupe que se instaló en el centro de un retablo. ${ }^{52}$ Es sabido que doña Bernarda Isabel Pérez Domínguez, que participó en actividades comerciales con el Nuevo Mundo, fundó la Capilla de los Dolores

47 VV.AA.: Los indianos. El arte colonial en Cantabria. Catálogo de la exposición celebrada en el Centro Cultural Caja Cantabria entre el 19 de Noviembre y el 20 de Diciembre de 1992, Centro Cultural Caja Cantabria, Santander, 1992, pág. 121.

48 Ibídem, pág. 132.

49 Ibídem, págs. 121, 124, 129, 132 y 134.

50 Martínez de la Peña: "Pinturas mejicanas del siglo XVIII en Tenerife"..., págs. 599-600.

51 Martínez, Rafael: "Notas para el estudio del patronazgo de indianos palentinos", VV.AA.: Relaciones artísticas entre la Península Ibérica y América..., págs. 163-172.

52 Gómez Díaz, Ana María: "Sanlúcar americana”, en Gómez Díaz, Ana María: Guía histórico artística de Sanlúcar. Asociación sanluqueña de encuentros con la Historia y el Arte, Sanlúcar de Barrameda—Cádiz—, 1993, págs. 139-200. 
del Convento franciscano de Icod de los Vinos - Tenerife-, que albergaba una pintura de la Virgen de Guadalupe.

Normalmente, para albergar una pintura se encargaba un pequeño retablo costeado por el indiano que solía situarse a un lado del altar principal. Un ejemplo es la pintura de la Virgen de Guadalupe que se halla en el retablo mayor de la Iglesia de Santa María de Axpe-Busturia - Vizcaya-, donada por el capitán de infantería don José de Apráiz y Arrospide en $1792 .{ }^{53}$ El historiador Genaro Estrada recoge la existencia de un altar formado por siete lienzos dedicado a la Virgen de Guadalupe en la Iglesia de San Salvador de Guetaria — Guipúzcoa—, al parecer donación de algún vasco de esa localidad que residió en México. ${ }^{54}$ Una información del historiador Francisco de la Maza nos indica que el cuadro enconchado de la Virgen de Guadalupe que permanece en el retablo mayor de la iglesia del Convento de Capuchinas de Toledo se considera un regalo de los patronos del templo efectuado hacia 1665 , año en que se fundó el convento mexicano filial de este..$^{55}$

En el libro de inventarios de alhajas y vestuario de 1787 de la Iglesia de San Juan Bautista de Murcia consta que don Francisco Algarra envió a dicha parroquia desde México, entre otros objetos, "una imagen de Nra. Sra. de Guadalupe con su retablo dorado". Y en el Inventario de 1832 figura "un cuadro de Ntra. Sra. de Guadalupe que lo envió don Francisco de Algarra y está en su altar". ${ }^{56}$ Por su parte, don Antonio Obregón Alcocer, natural de Llerana - Santander- que marchó a México, donó el retablo

53 Zorrozúa Santisteban, Julen: "Representaciones de la Virgen de Guadalupe en Vizcaya", Revista Letras de Deusto, . $^{\circ} 73$, vol 26, Oct-Dic 1996, Universidad de Deusto, Bilbao, 1996, págs. 139152. Esta investigación es la más amplia de las alusivas a la pintura novohispana en el País Vasco. Cita un buen número de guadalupanas y las relaciona con el fenómeno del mecenazgo indiano, tan importante en esta región.

54 Estrada: El arte mexicano conservado en España..., pág. 18. En el catálogo de la exposición Barroco importado en Álava y diócesis de Vitoria se menciona un altar dedicado a la Virgen de Guadalupe formado por cinco lienzos que fueron donados por José María Azcárate. Quizás se refiera al que se encuentra en la Iglesia de San Salvador de Guetaria — Guipúzcoa-. VV.AA.: Barroco impor tado en Álava y diócesis de Vitoria. Escultura y pintura. Catálogo de la exposición celebrada en la Sala América de Vitoria del 7 de Abril al 9 de Julio de 1995, Diputación Foral de Álava, Vitoria, 1995, págs. 137-141.

55 Maza, Francisco de la: Cartas barrocas desde Castilla y Andalucía, Universidad Nacional Autónoma de México, Instituto de Investigaciones Estéticas, México, 1963, pág. 100.

56 López Jiménez, José Crisanto: "Pinturas mexicanas en Murcia y un tríptico murciano de Nuestra Señora de Guadalupe", Anales del Instituto de Investigaciones Estéticas, $n .^{\circ} 32$, Universidad Nacional Autónoma de México, México, 1963, págs. 60-61. Este estudio, además de recoger varias obras de la Virgen de Guadalupe, informa sobre la influencia de la pintura guadalupana en artistas murcianos. 
con el lienzo de la Virgen de Guadalupe que hay en el lado del evangelio de la iglesia parroquial de dicho pueblo..$^{57}$

A veces un epígrafe aclaraba la identidad del responsable del legado. La pintura de la Virgen de Guadalupe localizada en el Convento de la Purísima Concepción de Segura - Guipúzcoa- ocupa el centro de un retablo con una inscripción en el entablamento que reza: "ESTE RETABLO LO HIZO LA MUNIFICENCIA Y DEVOCIÓN DE DON JOSÉ JOAQUÍN DE ARIZCORRETA AÑO $1790 " .58$

El historiador Alberto Ibáñez recoge muchas de las representaciones guadalupanas conservadas en la provincia de Burgos, la mayoría de las cuales van unidas a un retablo. ${ }^{59}$ Señala que la pintura que se ubica en la Iglesia parroquial de la Asunción de Nuestra Señora de Prádanos de Bureba fue donada por el emigrante don Felipe López Temiño y se sitúa en un retablo costeado en 1799 por un descendiente suyo, don José López Temiño, cura de esta iglesia, según consta en una inscripción del banco. La imagen que alberga la Iglesia parroquial de Urria ocupa un lugar preferente en un pequeño retablo adosado al muro del evangelio. La situada en la Iglesia parroquial de San Juan de Oña se incluyó en el remate del retablo del altar mayor, lo que constituye un caso insólito en la diócesis burgalesa y sólo se explica por la categoría del donante. En cuanto a la que se conserva en la Iglesia parroquial de Santibáñez Zarzaguda, de gran calidad artística, se inserta en un retablo donado por don Rafael Celada y Ortega en 1790. También la existente en la Iglesia parroquial de Quincoces de Yuso preside un retablo en la capilla funeraria de la familia Robredo. Y la custodiada en la Iglesia parroquial de Condado de Valdivieso se halla en un retablo junto a la Capilla de los Porres. Según explica este historiador, todas las pinturas guadalupanas situadas en templos burgaleses se deben a donativos de particulares en los que únicamente varía la condición del donante.

El autor Carlos García Peña indica que en la iglesia del Monasterio de San Miguel Arcángel de El Puerto de Santa María —Cádiz- se encontraba un retablo dedicado a Nuestra Señora de Guadalupe financiado por el

57 VV.AA.: Los indianos..., pág. 129.

58 Astiazarain, M. ${ }^{\text {a }}$ Isabel: "La iconografía de la Virgen de Guadalupe. Dos cuadros de Miguel Cabrera en Guipúzcoa", Cuadernos de Arte Colonial, n. ${ }^{\circ}$ 7, Museo de América, Madrid, 1991, pág. 143.

59 Ibáñez Pérez: "Relaciones artísticas entre Burgos y América. La Virgen de Guadalupe en Burgos"..., pág. 141. 
presbítero don Juan de Palma Torón donde probablemente se situara la pintura de la Virgen de Guadalupe que se conserva en el monasterio. ${ }^{60}$

En la Iglesia parroquial de Montemolín —Badajoz- se conserva un cuadro de la Virgen de Guadalupe del artista Francisco Antonio Vallejo instalado en un retablo sufragado en 1787 por el donante del cuadro, don José Navarro del Coro, "vecino de México y oriundo de esta villa extremeña". ${ }^{61}$

La Escena de la Cuarta Aparición de la Virgen de Guadalupe atribuida a Juan Dualde que se exhibe en el Museo de la Colegiata de San Luis de Villagarcía de Campos — Valladolid - fue llevada por la condesa Paredes de Nava, esposa del virrey de Nueva España Tomás Antonio de la Cerda, y hacia 1689 formó parte de un retablo ubicado en la sacristía de la iglesia.

Una de las muestras más significativas es el retablo dedicado a Nuestra Señora de Guadalupe que se encuentra en la Capilla de San Nicolás de la Mezquita-Catedral de Córdoba. Consta de cinco lienzos: el central representa a la Virgen de Guadalupe, y los otros cuatro, de menor tamaño, las escenas de la aparición de la Virgen al indio Juan Diego. Una información publicada por la historiadora María Ángeles Raya revela que encargado en 1670 por don Francisco Ruiz de Paniagua por 500 ducados. ${ }^{62}$

En ocasiones estas pinturas tenían función de exvotos, como cumplimiento de una promesa hecha a Dios o a la Virgen. Además de imágenes de las principales advocaciones novohispanas - casi siempre la Virgen de Guadalupe-, algunos legaban su retrato con una inscripción que lo acreditaba como el fundador de la capilla. El franciscano fray Francisco de San Buenaventura Tejada, natural de Espartinas - Sevilla-, obispo de Yucatán y Guadalajara - México-, a su regreso donó al Convento de Nuestra Señora de Loreto de su villa natal — donde se conserva una pintura de la Virgen de Guadalupe- imágenes de culto, ajuar litúrgico y un retrato suyo. ${ }^{63}$

Un hecho que demuestra el cometido que cumplían estas pinturas y a la vez nos informa de la identidad del personaje que las encargaba es que

60 García Peña, Carlos: Los monasterios de Santa María de la Victoria y San Miguel Arcángel en el Puerto de Santa María, Diputación de Cádiz, Jerez de la Frontera —Cádiz-, 1985, págs. 69 y 96.

61 Esteras Martín: "Presencia del arte novohispano en la Baja Extremadura”..., pág. 289.

62 Raya Raya, María Ángeles: Catálogo de las pinturas de la Catedral de Córdoba, Publicaciones del Monte de Piedad y Caja de Ahorros de Córdoba, Cajasur, Córdoba, 1988, págs. 60-61.

63 VV.AA.: "Donaciones artísticas de obispos franciscanos en América a instituciones españolas”, Actas del I Congreso Internacional sobre los franciscanos en el Nuevo Mundo. La Rábida —Huelva_, 16-21 de Septiembre de 1985, Deimos, D. L., Madrid, 1987, págs. 983-989. 
los cuadros de la Virgen de Guadalupe incluían a menudo una leyenda que rezaba: "A devoción..." seguida por el nombre del benefactor. Entre las múltiples muestras podemos mencionar el que posee la Hermandad de la Veracruz de Alcalá del Río — Sevilla—, en cuya inscripción se puede leer: "A devoción del Capp. D. Juan de Reina". Igualmente, la representación guadalupana situada en la Colegiata de Berlanga del Duero - Soriaposee una inscripción que comunica que fue realizada: "A devoción de Dn. Manuel Tajueco Álvarez Natural de esta Villa".

Otra dedicatoria la podemos observar en el lienzo de la Virgen de Guadalupe que se ubica en la Iglesia de Santiurde de Toranzo - Santander- , en este caso se lee: “A DEVOCIÓN DE DN. ÁLVARO GONZÁLEZ DE LA PORTILLA. EN MÉXICO, POR JOSÉ DE IBARRA. AÑO DE 1740”.

El situado en la iglesia del Hospital de las Misericordias - antiguo Convento de Padres Mínimos- de Puerto Real —Cádiz-, pintado por Miguel Correa en 1718, incluye una inscripción que revela que fue realizado "A devoción de el Cap. Pn. Don Juan Francisco...".

También el que se encuentra en la Iglesia de San Miguel de Castillo y Elejabeitia - Vizcaya-, pintado por el prestigioso artista novohispano Miguel Cabrera incluye una leyenda que aclara que se realizó "a devoción de Dn. Franco. Antt ${ }^{\circ}$. Eguiluz natural de Arteaga en el Señorío de Viz/caya, año de 1754".

En el retrato de la Virgen de Guadalupe obra de José de Alcíbar que se expone en el Museo de América podemos constatar que fue pintado "A la devoción del Esmo Sr. D. Sebastián de Medina y Osorio. Oidor de la Real Audiencia de México. Año 1766".

A veces la inscripción ofrece abundante información acerca del personaje que encargaba la pintura y los cargos que desempeñaba. Una muestra es la pintura de la Virgen de Guadalupe propiedad de los herederos del sevillano don Carlos Serra y Pickman, marqués de San José de Serra, realizada sobre lámina de cobre por Francisco Antonio Vallejo, en cuya cartela se lee: "A devoción del Excmo. Señor Bailio Fr. Don Antonio María Bucareli y Ursúa, Henestro/sa, Laso de la Vega, Villasís y Córdova, Caballero Gra/Cruz, Comendador de la Bóveda de Toro en el Orden de San Juan;/ Gentil Hombre de Cámara de S. M. con entrada/Teniente General de los Reales Exércitos Virrey/Gobernador y Capitán Gen. de esta Nueva España/Presidente de su Real Au/diencia, Superintendente General de Real Hacienda, Presidente de la Junta de/Tabacos, Juez Conservador de éste 
Ramo, Subdelegado General del nuevo establecimiento de Correos en este Reyno". ${ }^{64}$

Pero esta práctica no es exclusiva de pinturas con temática guadalupana. El lienzo del Cristo del Cardonal que se emplaza en el Convento del Santísimo Sacramento de Murcia, pintado por Andrés López en 1785, tiene una inscripción en la que figura: "A devoción de Dn. Ignacio José de Tapia vezino de México". ${ }^{65}$

Incluso, existen casos en los que el donante aparece dibujado en el cuadro, como sucede en el lienzo de la Inmaculada, obra de Juan Correa, que se halla en el Convento de Dominicas de Tudela — Navarra—. De este modo el artista sitúa al cliente junto a su advocación favorita.

En la pintura de la Virgen de Guadalupe que se conserva en la Colegiata de Berlanga del Duero - Soria — puede apreciarse en el ángulo inferior izquierdo el busto de su donante, don Manuel Tajueco Álvarez. Esto también sucede en la Escena de la Cuarta Aparición de la Virgen de Guadalupe, obra de Simón Petti, que se encuentra en el claustro del Convento de clausura de las Madres Carmelitas de Alba de Tormes - Salamanca-. Junto al indio Juan Diego y el joven clérigo Juan González aparecen otros dos personajes. Uno de ellos ha sido identificado por Elisa Vargas Lugo como el donante. Según Antonio Casaseca, este cuadro probablemente esté relacionado con el arzobispo de México y el obispo de Puebla. ${ }^{66}$

El historiador Fernando Guillamas informaba de que existió en Sanlúcar de Barrameda un lienzo de la Virgen de Guadalupe con la figura de su donante a los pies y rodeado de los tradicionales símbolos marianos. ${ }^{67}$ Este cuadro ha desaparecido de su primitivo emplazamiento en la Capilla del Santísimo Sacramento de la Iglesia parroquial de Nuestra Señora de la $\mathrm{O}$.

A veces el tema y el texto que acompañaba a la imagen aludían al arrepentimiento de la persona, con lo que su finalidad quedaba especificada. De ello se infiere que muchas de estas obras fueron realizadas por encargo. Una muestra bastante original es la pintura que el duque de Alburquerque, virrey de Nueva España, le solicitó al pintor José de

64 González Moreno: Iconografía guadalupana en Andalucía..., pág. 82.

65 Cuadriello: "La propagación de las devociones novohispanas...,, pág. 298.

66 Casaseca Casaseca: “Arte colonial en Salamanca”..., págs. 59-67.

67 Guillamas y Galiano, Fernando: Historia de Sanlúcar de Barrameda, Madrid, 1858, pág. 64. 
Arellano en 1709, titulada "Traslado de la imagen y estreno del santuario de Guadalupe" y ubicada en el palacio familiar en Madrid.

Son muchos los casos en los que el origen de estas donaciones está documentado. A veces una inscripción en el cuadro aclara esta cuestión. Así se sabe, por ejemplo, que la Virgen de Guadalupe de Miguel Cabrera que permanece en el Museo de América de Madrid fue pintada por mandato del "Excmo. Sr. D. Pedro Cebrián y Agustín, conde de Fuenclara, Sr. de Traella y Alcamín, Virrey de Nueva España”.

Otra muestra la tenemos en una pintura de la Sagrada Familia realizada sobre lámina de cobre por el artista mexicano José María Vázquez que forma parte de una colección particular madrileña. En su reverso aparece escrita una leyenda autógrafa que dice lo siguiente: "Dn. Joseph Asensio de Uriarte le Embio á/ su Mujer Da Inés de la Mella, este cua/ dro con su Marco de Plata con 22 onzas/ que pezan; en el año y mes de octubre 24 de/ 1795 años". 68

Doña Isabel Moreno Caballero, fundadora del Beaterio de la Santísima Trinidad de Sevilla, embarcó hacia Nueva España para recoger limosnas, trayendo a su regreso, en 1750, un gran lienzo de la Virgen de Guadalupe obra de fray Miguel de Herrera tal y como atestiguan unas inscripciones. ${ }^{69}$

La historiadora María Isabel Astiazaráin indica que en el coro de la Parroquia de Santa María de Uribarri de Durango - Vizcaya - se veneraba un cuadro de la Virgen de Guadalupe que desapareció tras la guerra civil, donado según su inscripción por "D. Ambrosio de Meabe, vecino de México y natural de aquella villa en $1764 "{ }^{70}$ En el mismo templo se conserva otro en cuya inscripción puede leerse: "EL ILTRE MEXICANO HIJO ADOPTIVO DE ESTA VILLA D. SALVADOR UGARTE/VIZCAÍNO DONÓ ESTE CUADRO A LA VILLA DE DURANGO XII-X-MCMLI".

El lienzo de la Virgen de Guadalupe existente en la Iglesia de Nuestra Señora del Carmen de Lucena incluye una inscripción que informa: "Esta

68 Esteras Martín, Cristina: “Una pintura inédita del mexicano José María Vázquez en Madrid. Aportaciones al estudio de su obra", Archivo Español de Arte, $n^{o}$ 229, Consejo Superior de Investigaciones Científicas, Departamento de Historia del Arte Diego Velázquez, Centro de Estudios Históricos, Madrid, 1985, pág. 300.

69 González Gómez, Juan Miguel y Morillas Alcázar, José María: Un ejemplo del mecenazgo americano en Sevilla: el Beaterio de la Santísima Trinidad, Universidad de Sevilla, Sevilla, 1990, págs. 23-27. En el Beaterio se conserva otro lienzo guadalupano probablemente también traído por la Madre Isabel.

70 Astiazarain: "La iconografía de la Virgen de Guadalupe...”..., págs. 140-141. 
anta ymagen de María santísima de Guadalupe de Méjico, vino de dicha ciudad a Lucena. Remitiola don Antonio Barzo Ibáñez de Texada al Padre Fray Juen del Santísimo Sacramento, prior de esta casa de Carmelitas Descalzos de Lucena, en 25 de marzo, martes, de 1725".

Sor María Ignacia de Jesús Nazareno, quien fuera religiosa del Convento de la Purísima Concepción de Segura —Guipúzcoa—, profesaba una gran devoción a la Guadalupana. Su hermano, don José Joaquín de Arizcorreta, donó a dicho convento en 1761, entre otras piezas artísticas, una pintura de la Virgen de Guadalupe como atestigua una inscripción en el retablo y otra en el lienzo. ${ }^{71}$

La representación guadalupana que permanece en la sacristía de la Iglesia de Santo Toribio de Mogroviejo de Mayorga de Campos — Valladolid_- obra de Juan Correa, fue entregada el 9 de noviembre de 1737 por doña María Miguel, viuda de don Bernardino Vela Benavides Cabeza de Vaca, en nombre de don Juan Manuel Vela Benavides, canónigo de la Catedral de Oviedo. En el reverso lleva escrito: "Don Andrés Benito Llanes Cienfuegos". ${ }^{72}$

La pintura de la Virgen de Guadalupe conservada en la Iglesia de San Nicolás de Tudela —-Pamplona_-, firmada por el artista Antonio de Torres lleva una leyenda en la que se lee: "Del General D-o-n Pedro Ramírez de Arellano".

También gracias a su inscripción podemos saber que el lienzo de la Virgen de Guadalupe que se halla en el Convento de San Antonio de Padua de Herbón - Padrón, La Coruña - fue donada por fray Andrés de Pazos, quien en 1714 marchó de este pueblo hacia Querétaro -México—. ${ }^{73}$

La pintura de la Virgen de Guadalupe conservada en la Iglesia de San Marcos de Icod - Tenerife- tiene una inscripción que revela que fue un donativo de don Pedro Hernández Ramos efectuado en $1721 .^{74}$

71 Ibídem, pág. 141. Hay que señalar que una información que recoge esta investigadora, según la cual doña Beatriz de Arrúe, de ascendencia guipuzcoana, financió el Convento de la Purísima Concepción de Segura, y además de obras de platería trajo alguna imagen devocional de América.

72 VV.AA.: Catálogo de la exposición de Arte Americano en Castilla y León celebrada en la Iglesia de la Magdalena de Valladolid entre el 11 de Noviembre y el 11 de Diciembre de 1992..., págs. 95-96.

73 Monterroso Montero, Juan Manuel: "La pintura barroca procedente de otras escuelas”, $\mathrm{La}$ pintura barroca en Galicia (1620-1750) — Tesis Doctoral—. Universidad de Santiago de Compostela, Santiago de Compostela, 1996, págs. 404-457. Este capítulo da a conocer varias pinturas novohispanas de diversas temáticas situadas en Galicia. Aprovecho esta oportunidad para agradecer al Doctor Monterroso la información e imágenes ofrecidas.

74 Fraga González: "Nueva relación de pinturas mexicanas en Canarias”..., págs. 898-899. 
Las pinturas de mayor calidad, en muchos casos óleos enconchados o realizadas sobre láminas de metal —en general zinc o cobre—, solían pasar a formar parte de oratorios privados. Por lo general eran obras de mayor tamaño y firmadas por los artistas más prestigiosos. En el Archivo General del Palacio Arzobispal de Sevilla se custodia un expediente de licencia para celebrar misas en el oratorio del ilustre sevillano don Tomás Céspedes y Sandoval, fechado el 27 de febrero de 1715, en el que se encontraba "un altar mazizo hecho de material con una Ymagen de Pintura de Nuestra Sra. de Guadalupe de México colocada en un arco con primor y aseo". ${ }^{75}$

Otro ejemplo lo constituye la pintura de la Virgen de Guadalupe que alberga el Oratorio de la Santa Cueva de Cádiz, pintada por el artista Antonio de Torres, que perteneció al oratorio privado del marqués de VadeÍñigo. ${ }^{76}$

Además localizamos pinturas guadalupanas realizadas sobre lámina de cobre en varias instituciones de la provincia de Burgos como el Monasterio de Santo Domingo de Silos, el de Monjas Clarisas de Castil de Lences y la antigua Colegiata de Covarrubias. También en colecciones particulares de Villarcayo e Ibrillos. ${ }^{77}$

Respecto a los óleos enconchados existen informaciones que señalan que José Sarmiento y Valladares, virrey de Nueva España entre 1696 y 1701, fue el responsable de muchos de estos envíos a la corte. ${ }^{78}$ El carácter de estas obras no era devocional. Aún así, su temática es en muchos casos religiosa. El abogado don Juan Antonio del Rivero, ligado profesionalmente a Carlos II y Felipe V poseía en 1717 "dos pinturas ochavadas, la una de Nuestra Señora de la Concepción con sus atributos y la otra del Angel San Miguel con el dragón a sus pies, embutidos en nácar, de una bara y quuarta de alto y una de ancho poco más o menos". ${ }^{79}$ Según el historiador Manuel Toussaint este tipo de pinturas se realizaron entre 1692 y 1752. Muchas constan en documentos conservados en el Archivo de los Alcaldes ordina-

75 Archivo General del Palacio Arzobispal de Sevilla. Salón de Documentos de la Curia. 30 de Oratorios, n. ${ }^{\circ} 5$.

76 Datos ofrecidos por el Instituto Andaluz del Patrimonio Histórico.

77 Ibáñez Pérez: "Relaciones artísticas entre Burgos y América. La Virgen de Guadalupe en Burgos"..., pág. 141.

78 García Sáiz, María Concepción: "Catálogo. Nuevos materiales para nuevas expresiones", Los Siglos de Oro en los virreinatos de América. 1550-1700, Museo de América, Madrid, 2000, pág. 135 .

79 García Sáiz, María Concepción: “Arte colonial mexicano en España”, Revista Artes de México, n. ${ }^{\circ} 22$, 1993-1994, Jean Paul Getty Trust, México, 1994, págs. 26-38. 
rios y Corregidores de la ciudad de México, donde se los denominaba indistintamente cuadros, lienzos, imágenes, tableros o láminas. ${ }^{80}$

Junto a los enconchados, hubo obras de arte bastante apreciadas en España como los cuadros de plumería o los biombos pintados. Estos, originalmente importados de China, fueron frecuentes en los palacios mexicanos durante la época virreinal. Generalmente pertenecían personajes de alto nivel adquisitivo dedicados con frecuencia al coleccionismo. El historiador Enrique Marco Dorta informaba de que el aristócrata sevillano conde de Bustillo poseía un biombo mexicano del siglo XVIII pintado al óleo en el que aparecía la villa y la Basílica de Guadalupe. Además aludía a otros dos, uno de ellos firmado por Juan Correa, localizados en colecciones particulares sevillanas. ${ }^{81}$ Joaquín González Moreno documenta uno perteneciente a la colección Armero Manjón de Sevilla, pintado por ambas caras con un paisaje del cerro del Tepeyac donde se encuentra el Santuario de la Virgen de Guadalupe. ${ }^{82}$

Varios tipos de documentos nos permiten conocer el destino de estas obras, aunque éste fue variando con la muerte de sus propietarios originales y muchas de ellas fueron vendidas, saliendo a veces al extranjero. Los Bienes de Difuntos son un material imprescindible para el estudio del arte indiano en España. Estos son los objetos personales dejados en las Indias por españoles o extranjeros fallecidos en esas tierras o durante la travesía, sin herederos en el Nuevo Mundo. Con el propósito de hacerlos llegar a manos de sus legítimos destinatarios, la corona española creó hacia 1550 el Juzgado de Bienes de Difuntos. A través del cumplimiento de las mandas estipuladas en el testamento se iniciaba un amplio expediente. En los casos en los que no existía testamento se presentaba únicamente un inventario de bienes con la evaluación y la almoneda de los mismos. El envío de estos bienes a España provocó en ocasiones litigios entre las partes como puede comprobarse en numerosos expedientes albergados en las secciones de Justicia y Escribanía de Cámara del Archivo de Indias de Sevilla.

Dentro de la documentación de Bienes de Difuntos se incluyen escritos de diversa índole como testamentos, disposiciones de última voluntad... que

80 Toussaint, Manuel: "La pintura con incrustaciones de nácar en Nueva España", Anales del Instituto de Investigaciones Estéticas, $n^{\circ}$ 20, Universidad Nacional Autónoma de México, México, 1952, págs. 5-20.

81 Marco Dorta, Enrique: "Un biombo mexicano del siglo XVIII", Archivo Español de Arte, $n^{\circ}$ 17. Instituto Diego Velázquez, Consejo Superior de Investigaciones Científicas, Madrid, 1944, págs. 70-76.

82 González Moreno: Iconografía guadalupana en Andalucía..., pág. 185. 
ofrecen datos acerca del nivel económico y sociocultural de estos personajes. También los inventarios postmortem, tasaciones, cartas privadas que a veces aparecen en los autos o las peticiones de los herederos aportan interesante información. Los inventarios, que eran realizados por un albacea, solían ser cortos e incluir dinero, ropa y utensilios personales. La mayoría de los expedientes se iniciaban en la Península. Los Bienes de Difuntos llegaban a la Casa de la Contratación y desde allí se hacían llegar a sus destinatarios. Al arribar el barco a puerto, ésta hacía pública la lista de los bienes, y si sus herederos no los reclamaban se enviaba a un alguacil para notificárselo.

Con frecuencia el lugar de origen estaba presente a la hora de redactar un testamento. Esto se manifestaba principalmente de tres formas: legados a familiares o pago de deudas, devociones locales - a veces compartidas con otras americanas-y donativos para obras sociales. En la primera el heredero, que solía ser un varón, a menudo era designado patrono de una capellanía, lo que implicaba la obligación de celebrar un determinado número de misas.

Los testamentos nos permiten conocer las características de muchas obras y ofrecen noticias referentes al origen, estado civil y actividad que desempeñó la persona. Además, el examen de los objetos religiosos que poseían nos da una visión de su espiritualidad. Entre los del sargento mayor de flota don Diego Osorio encontramos "un rosario engastado en plata, y dentro lleva una imagen de Nuestra Señora de Guadalupe pintada en lienzo". ${ }^{83}$

Conocemos ciertos casos de legados testamentarios en los que se incluyen pinturas novohispanas. La de la Virgen de Guadalupe obra de Manuel Osorio que se encuentra en la Catedral de Palencia fue donada en don Román Ovejero en cumplimiento de la última voluntad de su esposa doña María Bárbara Díez Quijada, en cuyo testamento, fechado el 14 de marzo de 1846, expresaba: "Mando a la Sta. Iglesia Catedral de esta Ciudad la Imagen grande de pintura de Nra. S ${ }^{a}$ de Guadalupe". Su padre, don Félix Díez Quijada, fue oidor de la Audiencia de México, lo que sin duda explica la tenencia de esta obra. ${ }^{84}$ Por otro lado, Don Martín de Lariz

83 Archivo General de Indias. Contratación, 465, n. ${ }^{\circ} 19$.

84 Martínez González, Rafael: "A propósito de la Virgen de Guadalupe de la Catedral de Palencia", Publicaciones de la Institución Tello Téllez de Meneses, Pttm. 63, Diputación provincial de Palencia, Palencia, 1992, págs. 751-757. Un estudio reciente publicado por este investigador revela que un elevado número de palentinos emigraron a América, muchos de los cuales eran personajes importantes: tres virreyes de Nueva España, obispos, presidentes de audiencia... Martínez, Rafael: "Notas para el estudio del patronazgo de indianos palentinos", VV.AA..: Relaciones artísticas entre la Península Ibérica y América..., págs. 163-172. 
Olaeta, natural de Puebla de Ea - Vizcaya- dispuso en su testamento, redactado en 1723, el envío de 1.000 pesos de plata para construir en la Iglesia de Santa María de Jesús de esa localidad una capilla con la advocación de Nuestra Señora de Guadalupe "en la cual se colocará un lienzo de su Santa Imagen con sus quatro apariciones y otro lienzo del Santísimo Xripsto de Zacatecas". ${ }^{85}$ Del mismo modo, el indiano don Diego García de Olloqui y Polo, oriundo del pueblo navarro de Villafranca, dictaminó en su testamento, redactado en 1692, "que en una de las colaterales de su yglesia se ponga el quadro de la madre de Dios de Guadalupe que trajo de Indias por dejarlo también de limosna a la dicha Vasílica del Portal". ${ }^{86}$

Según datos ofrecidos por el investigador Juan Manuel Monterroso, la pintura de la Virgen de Guadalupe situada en el Monasterio de Valdeflores de Vivero - Lugo - fue un donativo del presbítero don Luis López, natural de este pueblo, a través de su testamento, realizado en México. ${ }^{87}$ En la Ermita de Nuestra Señora de la Caridad de Huelva se veneraba un cuadro de la Virgen de Guadalupe legado según disposición testamentaria realizada por doña Catalina Camero el 28 de septiembre de 1757 ante el párroco don Andrés González Valiente. ${ }^{88}$

Algunos de estos inventarios revelan noticias curiosas como la tasación de las obras. De este modo sabemos que "una pintura de nuestra señora de Guadalupe de México de flores de dos varas y media caida sin marco" que había pertenecido al octavo duque de Veragua estaba valorada en 1734 en 400 reales, mientras que otra, propiedad del pintor Andrés de la Calleja y de similares características, en 1748 valía únicamente 100 reales. ${ }^{89}$

Son bastantes los inventarios de bienes de españoles que incluyen pinturas novohispanas. En el Archivo de Protocolos Notariales de Sevilla se conservan algunos de personajes sevillanos del siglo XVIII. En el de don Juan Soto de Nogueras, realizado por su viuda el 1 de julio de 1700, aparece "una lámina de la Familia Sacra en tabla, con su moldura, todo embutido en nácar, de media vara de alto". Además, en el apartado denominado "Pintura" figura "una lámina de NUESTRA SEÑORA DE GUADALUPE DE $139-152$.

85 Zorrozúa Santisteban: "Representaciones de la Virgen de Guadalupe en Vizcaya"..., págs.

86 Andrés Gallego, José y otros: Navarra y América, Ed. Mapfre, Madrid, 1992, pág. 188.

87 Monterroso Montero: "La pintura barroca procedente de otras escuelas"..., págs. 404-457.

88 González Moreno: Iconografía guadalupana en Andalucía..., pág. 70. Se ignora el paradero de este cuadro, pues donde estuvo ubicado el templo se encuentra el archivo del Banco Hispanoamericano.

89 García Sáiz: “Arte colonial mexicano en España”..., págs. 26-38. 
MÉXICO, sobre cobre, con su moldura dorada, de tres quartas de alto y media vara de ancho", y "un quadro de NUESTRA SEÑORA DE GUADALUPE, con su marco dorado calado, de dos varas pocos menos de alto y ciete quartos de ancho". 90

En el mismo archivo encontramos el inventario de bienes de don Domingo Urbizu, caballero de la orden de Calatrava y miembro del Consejo Real de Hacienda, realizado por su esposa en 1701. En él se recoge "un lienzo de NUESTRA SEÑORA DE GUADALUPE DE MEJICO CON SUS APARICIONES, sin moldura". ${ }^{91}$

En el de don Francisco Tello y Portugal, caballero de la orden de Alcántara y marqués de Sauseda, realizado el 20 de septiembre de 1702 por los marqueses de Paradas y de Sauseda, consta "una Ymagen de NUESTRA SEÑORA DE GUADUPE, hecha en Indias". ${ }^{2}$

De la misma manera, en el archivo de don Alejandro Carlos de Licht, hecho con motivo de la muerte de su esposa siendo él albacea testamentario, se incluye "una laminita de NUESTRA SEÑORA DE GUADALUPE, de una tercia de alto, con moldura de carey y los perfiles de marfil". ${ }^{93}$

Asimismo, en el inventario de bienes de doña Juliana Ortiz de Peralta, de 1702, están registradas "dos láminas de media bara con molduras doradas, la una de NUESTRA SEÑORA DE GUADALUPE y la otra del PADRE ULLOA". ${ }^{94}$

En el de doña Raphaela Antonia de la Vega Celis, realizado por su viudo en 1701, observamos "un lienzo de NUESTRA SEÑORA DE GUADALUPE DE INDIAS de a más de dos varas con marco grande dorado y azul, bien tratado". ${ }^{95}$

Esta documentación acredita la presencia de pinturas novohispanas en domicilios de diversos personajes sevillanos del siglo XVIII, la mayoría de elevado nivel social, que estuvieron de un modo u otro vinculados con el virreinato de Nueva España.

Como se constata en la mayoría de ellos, la imagen de la Virgen de Guadalupe es una constante. Según afirma el historiador mexicano Jaime Cuadriello, "los indianos nuevamente arraigados en sus provincias o

90 Archivo de Protocolos Notariales de Sevilla. Año 1700, oficio 19, libro 2. ${ }^{\text {13064, folios }}$ $510-532$.

91 APN Sevilla. Año 1701, oficio 24, libro 1. ${ }^{\circ} 17111$, folios 922-924.

92 APN Sevilla. Año 1702, oficio 13, libro 2. ${ }^{\circ} 8173$, folios 1623-1634

93 APN Sevilla. Año 1702, oficio 16, libro 2..$^{\circ} 10321$, folios 620-637.

94 APN Sevilla. Año 1702, oficio 16, libro 1. ${ }^{\circ} 10318$, folios 644-648.

95 APN Sevilla. Año 1702, oficio 18, libro 2. ${ }^{\circ} 3769$, folios 152-158. 


\section{PINTURAS NOVOHISPANAS EN ESPAÑA}

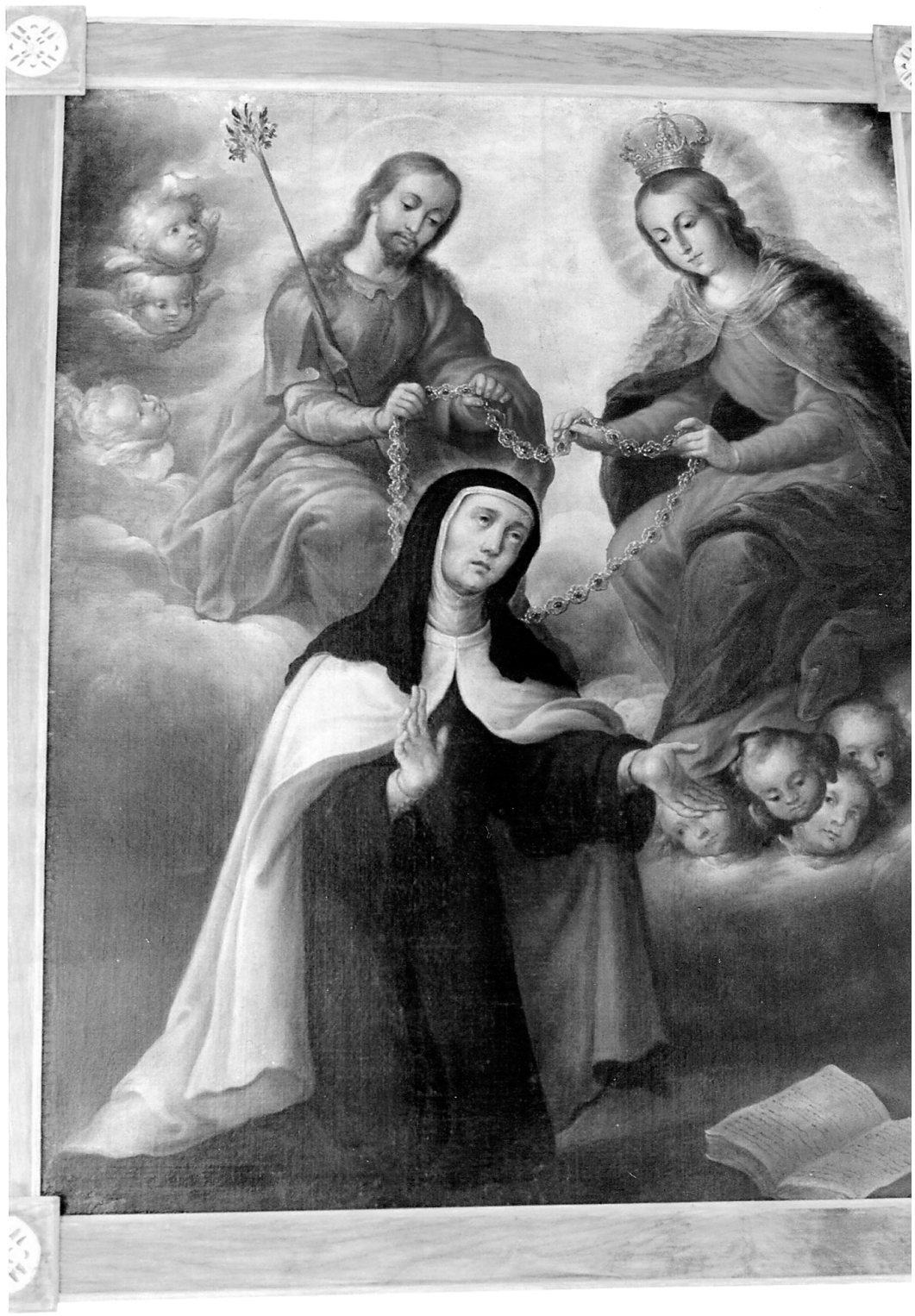

4. Visión de Santa Teresa. Claustro del Monasterio de Nuestra Señora de Valdeflores de Vivero (Lugo). Anónimo, finales del siglo XVII o primer tercio del siglo XVIII, óleo sobre lienzo. 


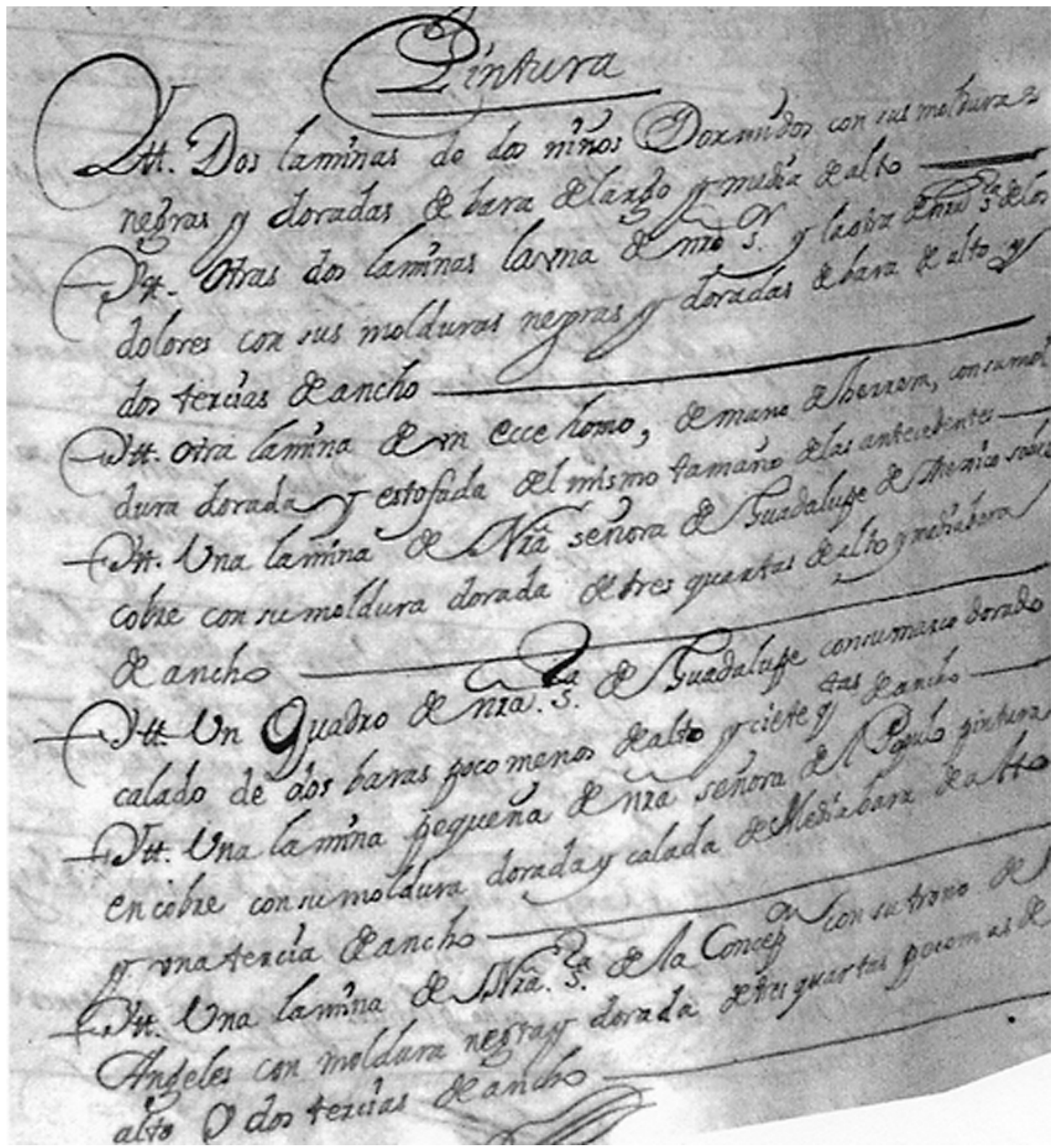

5. Inventario de bienes de don Juan de Soto y Nogueras hecho por su viuda, doña Jacinta Ortega. Sevilla, Julio de 1700. Archivo de Protocolos Notariales de Sevilla. Legajo 13.064. Oficio 19 , libro $2 .^{\circ}$, folios $519-532$. 
nostálgicos de ellas confiaban que la Virgen de Guadalupe de México sería trasmisora de sus crecientes cualidades taumatúrgicas". ${ }^{96}$

La devoción profesada a la Virgen de Guadalupe por los españoles afincados en tierras novohispanas se puede apreciar en distintos tipos de documentos. El testimonio más antiguo es el testamento de Bartolomé López, uno de los primeros conquistadores, redactado en 1537. En dos de sus cláusulas dispone: "mando a Nuestra Señora de Guadalupe, por mi ánima, cien Misas e se paguen de mis bienes", y "mando que se digan en la casa de nuestra Señora de Guadalupe cien Misas e se paguen de mis bienes". ${ }^{97}$

En el Archivo de Indias de Sevilla se conserva el testamento de don Antonio Tello de Meneses, comerciante natural de Cervera - "Castilla la Vieja"- difunto en México, quien testó el 21 de julio de 1784 indicando lo siguiente: "Instituyo, elijo y nombro por mi única y universal heredera a Nuestra Santissima Reyna y Patrona María Santísima de Guadalupe". ${ }^{8}$

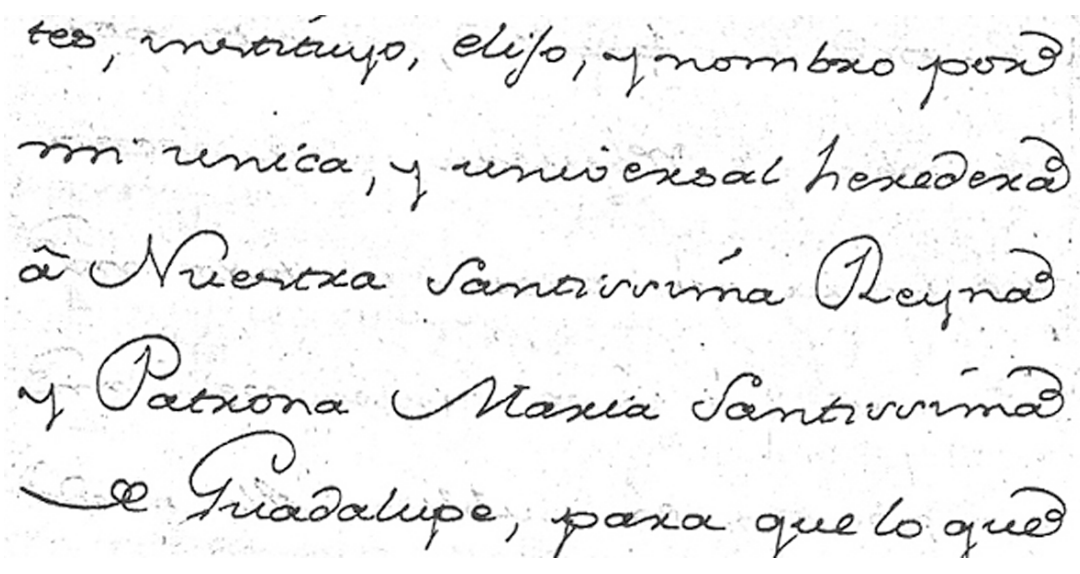

6. Autos sobre los Bienes de Difuntos de don Antonio Tello de Meneses, comerciante natural de Cervera (Castilla la Vieja), difunto en México, 1784. Heredera: la Virgen de Guadalupe. Archivo General de Indias. Contratación, 5694, N.1.

96 Cuadriello: "La propagación de las devociones novohispanas...”, pág. 263.

97 García Gutiérrez, Jesús: Primer siglo guadalupano. Documentación indígena y española (1531-1648), México, 1931, pág. 69.

98 AGI. Contratación, 5694, N.1. 
Las cartas personales son otra fuente constante de información. En una enviada a Cádiz por el virrey Bucarelli al almirante don Antonio Ulloa, fechada en México el 27 de marzo de 1778, le decía: “...así lo he pedido hoy a ntra Patrona de Guadalupe de cuyo Santuario vengo y donde he dejado la limosna para que se haga un Novenario de Misas, que conduzca a Vm a Cadiz como lo condujo el antecedente a la Habana". ${ }^{99}$ En la que le remitió poco después don Antonio Ulloa al virrey Bucarelli, fechada en Cádiz el 17 de julio de 1778, contestaba: "y particularmente invocando la protección de la Milagrosa imagen de Nuestra Sra. de Guadalupe, la particular protectora de todos los que la invocan con verdadera fe". ${ }^{100}$

Otro claro ejemplo de devoción a la Guadalupana queda de manifiesto en los autos de Santiago Belauzarán, natural de Guipúzcoa y difunto en Veracruz -México-, dejando como heredera a su hermana. Están fechados el 15 de enero de 1785, y ellos ordenan "más mandas forzosas y acostumbradas en que se incluye la beatificación del Venerable Siervo de Dios Gregorio López, y del Santuario de la Milagrosa Imagen de Nuestra Señora de Guadalupe que se venera en su Santa Iglesia Colegiata de la ciudad de México, mando se de a cada una a dos reales de plata, lo que se pague de mis bienes". ${ }^{101}$

En el Archivo de Indias se custodian gran cantidad de inventarios de bienes y legados testamentarios de españoles fallecidos en Nueva España que dejaron sus posesiones a familiares residentes en su villa natal. Éstas incluyen en ocasiones pinturas de origen novohispano. En los autos sobre los Bienes de Difuntos de Manuel López de Angulo, natural de Bianez - Vizcaya - difunto en Chilpancingo - México - con memoria testamentaria fechada en 1754, dejaba como heredera a su madre, y por su falta a su hermana. Entre sus bienes constaba "una Imagen de Nuestra Señora de los Dolores". ${ }^{102}$

En los de Francisco Ortiz de Navarrete, natural de Sevilla y médico del virrey de Nueva España que murió en México con testamento - 16361642 - designó como herederos a sus hijos, aparecen varias pinturas: "Un quadro grande de hechura de Un Crucifixo Y San Ignacio Y Santa teressa Con marco dorado", "otro quadro grande de nuestra Señora de la Concep-

99 AGI. Indiferente, $1632 \mathrm{~B}$.

100 AGI. Indiferente, 1632 B.

101 AGI. Contratación, 5695, N.1101117 y 31. El 7 de diciembre de 1756 Fernando VI ordenó en una real cédula que una de las mandas forzosas en los testamentos mexicanos fuera la del Santuario de Guadalupe. González Moreno: Iconografía guadalupana en Andalucía..., pág. 41.

102 AGI. Contratación, 5624, N.1\1\47. 
ción”, "otro quadro grande de nuestra Señora Y San Joseph", "otro quadro grande Con su marco dorado, de Tovias", "Dos quadros pequeños de hermitaños", "otro quadro Con su marco grande de susana Y los viejos", "otro quadro grande de abrahan", "otro quadro grande de adan Y eva", y "un quadro Pequeño de san Cosme y San Damián". ${ }^{103}$

En los Autos sobre los Bienes de Difuntos de Bernardo Ortiz de las Navedas - 1758 - , mercader natural de San Pedro del Romeral difunto en Colima - México- que designa como herederos a sus hermanos figuran "Un quadro de vara y quarta de la hechura de Nuestra Señora de Balbanera sin marco ya viejo" y "Siete cuadritos pequeños de a dos temas el uno del Señor San Joseph, otro de Nuestra Señora de la Soledad, otro de San Jerónimo, otro de San Francisco, otro de San Juan, otro de Nuestra Señora de Guadalupe, y el otro de San Miguel ya viejos". ${ }^{104}$

Otra vía de investigación es la que ofrece la importante serie de registros de navíos existente en el Archivo de Indias, donde quedaban consignadas todas las mercancías que procedían de América. La dificultad que presenta esta búsqueda es que en la mayoría de las ocasiones los productos no aparecen registrados de forma pormenorizada. En cuanto a las pinturas, el único proceso bien documentado es el envío de éstas al virreinato durante la primera etapa de la colonización, con objeto de su venta. En estos manuscritos figuraba su propietario, el barco en el que se trasladaban, el lugar al que se dirigían, e incluso el precio. En el envío hecho en 1599 a Nueva España por el vecino de Sevilla Andrés de Herbas en el navío Santa Elvira iban "Diez y ocho imágenes de Nuestra Señora y otras devociones, en láminas a veinte reales cada una". ${ }^{105}$

Aunque el transporte de obras de arte no está bien documentado, se conocen algunos datos que arrojan luz sobre el asunto. Al parecer, los cuadros venían muchas veces enrollados para su mejor resguardo y embalados en cajones. De esta forma, había que esperar a su llegada para poderlos insertar en sus bastidores y colocarlos en sus respectivos marcos. En la carta enviada por el Almirante Ulloa al virrey Bucarelli en 1778 queda patente que estos lienzos, tablas y cobres venían sin marco, y era en su lugar de destino donde se les daba la forma definitiva: "la laminita de nuestra Sa. de

103 AGI. Contratación, 543, N.1, R.3\1\30 Recto, 30 Verso.

104 AGI. Contratación, 5635, N.6\1\40 y 41.

105 Torre Revelo, José: "Obras de arte enviadas al Nuevo Mundo en los siglos XVI y XVII", Anales del Instituto de Investigaciones Estéticas, $n .^{\circ} 1$, Universidad Nacional Autónoma de México, México, 1948, págs. 92-93. 
Guadalupe con medias cañas la tomo la niña grandecita para ponerla a la cabecera de su cama... se le estan poniendo medias cañas, y cristales, lo mismo que a las láminas de las distintas castas de gentes del Reyno". ${ }^{106}$

También se sabe que el lienzo de la Virgen de Guadalupe que permanece en la iglesia de Santa Ana de Durango - Vizcaya - fue remitido a su destinatario por unos familiares desde México en un navío que zarpó de Veracruz, "enrollado en un tubular de fina caña mejicana que estaba forrado con una lámina de cinc en la que se leían, grabadas, estas cuatro palabras: "José Joaquín de Arguinzóniz, España". ${ }^{107}$

Además de las fuentes mencionadas, también los archivos parroquiales, fundaciones, capellanías, archivos históricos provinciales, catálogos de pasajeros a Indias conservados en el Archivo de Indias o las consultas del Consejo de Indias contienen información de interés.

En definitiva, hoy día permanece en España un amplio muestrario de pintura mexicana de los siglos XVII y XVIII, de iconografía principalmente guadalupana, concentrada sobre todo en las zonas que mantuvieron un mayor contacto con Nueva España. Se trata en líneas generales de lienzos, la mayor parte anónimos, con una función más devocional que artística, que evidencian un enriquecedor intercambio cultural en el que intervinieron aspectos sociales, económicos, religiosos y puramente humanos.

Gracias a la existencia de bastante documentación de la época y a las investigaciones realizadas durante los últimos años, es posible reconstruir, al menos en parte, el entorno en el que se produce este fenómeno y los factores que lo condicionan, así como las características y el significado de estas obras.

107 Astiazarain: "La iconografía de la Virgen de Guadalupe...”..., págs. 140-141. 